\title{
Present and future impact of aircraft, road traffic and shipping emissions on global tropospheric ozone
}

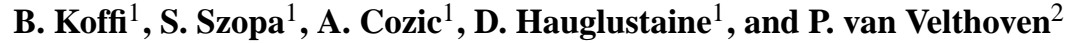 \\ ${ }^{1}$ Laboratoire des Sciences du Climat et de l'Environnement, UMR 8212, IPSL, CEA-CNRS-UVSQ, \\ Gif-sur-Yvette, France \\ ${ }^{2}$ Royal Netherlands Meteorological Institute, KNMI, De Bilt, The Netherlands
}

Received: 30 May 2010 - Published in Atmos. Chem. Phys. Discuss.: 28 June 2010

Revised: 17 November 2010 - Accepted: 21 November 2010 - Published: 9 December 2010

\begin{abstract}
In this study, the LMDz-INCA climate-chemistry model and up-to-date global emission inventories are used to investigate the "present" (2000) and future (2050) impacts of transport emissions (road traffic, shipping and aircraft) on global tropospheric ozone. For the first time, both impacts of emissions and climate changes on transport-induced ozone are investigated. The 2000 transport emissions are shown to mainly affect ozone in the Northern Hemisphere, with a maximum increase of the tropospheric column of up to $5 \mathrm{DU}$, from the South-eastern US to Central Europe. The impact is dominated by road traffic in the middle and upper troposphere, North of $40^{\circ} \mathrm{S}$, and by shipping in the northern lower troposphere, over oceanic regions. A strong reduction of road emissions and a moderate (B1 scenario) to high (A1B scenario) increase of the ship and aircraft emissions are projected by the year 2050. As a consequence, LMDz-INCA simulations predict a drastic decrease in the impact of road emissions, whereas aviation would become the major transport perturbation on tropospheric ozone, even in the case of a very optimistic aircraft mitigation scenario. The A1B emission scenario leads to an increase of the impact of transport on zonal mean ozone concentrations in 2050 by up to $+30 \%$ and $+50 \%$, in the Northern and Southern Hemispheres, respectively. Despite a similar total amount of global $\mathrm{NO}_{\mathrm{x}}$ emissions by the various transport sectors compared to 2000 , the overall impact on the tropospheric ozone column is increased everywhere in 2050 , due to a sectoral shift in the emissions of the respective transport modes. On the opposite, the B1 mitigation scenario leads to a significant reduction (by roughly $50 \%$ ) of the ozone perturbation throughout the troposphere compared to 2000 .
\end{abstract}

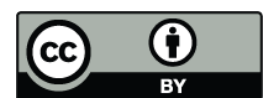

Correspondence to: B. Koffi (brigitte.koffi@1sce.ipsl.fr)
Considering climate change, and according to scenario A1B, a decrease of the $\mathrm{O}_{3}$ tropospheric burden is simulated by 2050 due to climate change $(-1.2 \%)$, whereas an increase of ozone of up to $2 \%$ is calculated in the upper troposphere in the inter-tropical zone, due to enhanced lightning activity. A global impact of similar magnitude is simulated for the transport-induced ozone burden perturbation $(-1.6 \%)$. As a result, the future increase in global ozone due to changes in anthropogenic emissions is lowered by $12 \%$ and by $4 \%$, for the background and the transport-induced ozone, respectively. However, positive and negative climate effects are obtained on ozone, depending on the season, region and altitude, with an increase of the transport-induced ozone perturbation $(+0.4 \mathrm{DU})$ in the already most affected area of Northern Hemisphere.

\section{Introduction}

Emissions from the transport sectors contribute globally for about $30 \%$ to $40 \%$ to global anthropogenic emissions of carbon monoxide and nitrogen oxides, respectively, and to about 25\% of anthropogenic Non Methane Hydrocarbon Compounds, NMHCs (e.g., Olivier at al., 2005). In the atmosphere, $\mathrm{CH}_{4}, \mathrm{CO}$ and NMHCs in presence of $\mathrm{NO}_{\mathrm{x}}$ act as ozone precursors by forming radicals which finally contribute to the ozone formation (Crutzen et al., 1999) and therefore, indirectly impact on climate. Fuglestvedt et al. (2008) found that transport has contributed to $31 \%$ of the total man-made $\mathrm{O}_{3}$ forcing, since preindustrial times. Unger et al. (2008) calculated that transport emissions in Europe and North America have a particularly large forcing and are therefore attractive targets to counter global warming. The chemical production of ozone is a highly non-linear function of emitted $\mathrm{NO}_{\mathrm{x}}$ and $\mathrm{NMHC}$ precursors, and is very sensitive

Published by Copernicus Publications on behalf of the European Geosciences Union. 
to local meteorology and atmospheric background composition. Besides their effect on the ozone concentration and its related radiative forcing, the emissions from transport also affect the $\mathrm{OH}$ concentration, i.e. the oxidizing capacity of the atmosphere (e.g., Niemeier et al., 2006). The emissions by the transport sector are expected to show drastic quantitative and geographic changes in the next decades, which in turn will affect air quality and climate (Kahn Ribeiro et al., 2007). Moreover, significant changes in climate conditions are expected to occur in the future (Meehl et al., 2007), affecting the atmospheric oxidation processes (Hedegaard et al., 2008), and thereby, possibly, the atmospheric perturbations induced by transport emissions.

In the last decade, several atmospheric model studies were performed to assess the global impact of present-day transport emissions on the chemical composition of the atmosphere, but focusing on a given transport mode.

The impact of $\mathrm{NO}_{\mathrm{x}}$ and $\mathrm{CO}$ current road emissions was first investigated by Granier and Brasseur (2003), who estimated their relative contribution between $12 \%$ and $15 \%$ and of about $9 \%$ of the ozone background near the surface, in industrial and remote regions, respectively. More recently, Matthes et al. (2007) concluded that the maximum relative impact of road traffic emissions $\left(\mathrm{NO}_{\mathrm{x}}, \mathrm{CO}, \mathrm{NMHC}\right)$ occurs at Northern mid-latitudes in July, contributing by up to $16 \%$ and $12 \%$ of the surface and zonal mean ozone concentrations, respectively. They also demonstrated the important role of NMHC that contribute to an indirect long-range transport of $\mathrm{NO}_{\mathrm{x}}$ from road traffic via the formation of PAN, and consequently, lead to a greater influence on ozone in remote areas (i.e., by $+30 \%$ ). Similar results were also obtained by Niemeier et al. (2006) who concluded that the road traffic emissions increase the zonally averaged tropospheric ozone concentration by more than $10 \%$ in the boundary layer, and by about $6 \%$ at $500 \mathrm{hPa}$ and $2.5 \%$ at $300 \mathrm{hPa}$, in July. Niemeier et al. (2006) and Matthes et al. (2007) reported changes in the July ozone surface concentration by $20 \%$ and by up to little more than $16 \%$ in source regions, respectively.

Many model studies investigated the present impact of international shipping on atmospheric chemistry, and more specifically on ozone (Lawrence and Crutzen, 1999; Corbett and Kohler, 2003; Endresen et al., 2003, 2007; Eyring et al., 2005a, 2007; Huszar et al., 2010). They underlined that ozone perturbations due to shipping is highly nonlinear, being most efficient in regions of low background pollution. These studies suggest an overall higher ozone production efficiency of $\mathrm{NO}_{\mathrm{x}}$ ship emissions, compared to road traffic emissions. However, they also mentioned important uncertainties associated to the total amount of emissions, the neglect of ship plume dispersion, and their spatial distribution. More recently, Dalsoren et al. (2009) calculated the impact from the international fleet of ships using updated emissions datasets from the EU QUANTIFY project (Quantifying the Climate Impact of Global and European Transport Systems; http://www.pa.op.dlr.de/quantify/). They found that ship emissions contribute for a large part to surface ozone over the oceans (up to $40 \%$ ), but also over some continental areas such as over Western America (15-25\%) and Western Europe (5-15\%). A contribution up to 5-6\% to the tropospheric ozone column was simulated over the North Atlantic. Huszar et al. (2010) found that the contribution of ship induced surface $\mathrm{NO}_{\mathrm{x}}$ to the total background reaches $90 \%$ over remote ocean, and makes 10-30\% near coastal regions. They calculated that due to ship emissions, surface ozone increases by up to $4-6 \mathrm{ppbv}$, making $10 \%$ contribution to the surface ozone budget.

The global impact of $\mathrm{NO}_{\mathrm{x}}$ emissions from subsonic aircraft on ozone has been extensively investigated (Hauglustaine et al., 1994; Brasseur et al., 1996, 1998a; Wauben et al., 1997; Stevenson et al., 1997; Schumann, 1997; Schumann et al., 2000; Dameris et al., 1998; Kentarchos and Roelofs, 2002; Grewe et al., 2002; Gauss et al., 2006; Cariolle et al., 2009). While representing less than $2 \%$ of the global current $\mathrm{NO}_{\mathrm{x}}$ emissions, the aircraft emissions are shown to lead to a significant ozone perturbation in the Upper Troposphere and Lower Stratosphere (UTLS), i.e., where $\mathrm{NO}_{\mathrm{x}}$ have a much higher ozone production potential than at Earth's surface, and where increases in ozone are known to cause an important radiative forcing (e.g., Sausen et al., 2005; Lee et al., 2009). First studies calculated for instance an increase by 2 up to $8 \%$ of the ozone background (Brasseur et al., 1998a). However, large differences, in both magnitude and seasonality, were highlighted between the different studies, resulting notably from the lack of NMHC chemistry, the coarse vertical resolution at the tropopause, quantitative uncertainties on $\mathrm{NO}_{\mathrm{x}}$ emissions by lightning and mass transport by convection (Grewe et al., 2002). More recently, Gauss et al. (2006) found a maximum increase in the monthly averaged zonal mean ozone in June (+7.6 ppbv) and a minimum in September ( $\sim 3 \mathrm{ppbv})$, and increase of $6 \mathrm{ppbv}$ for July. Last results from the NMHC version of the LMDz-INCA model, using AERO2K 2002 emissions (Eyers et al., 2004) show lower changes and different spatial patterns, with a maximum perturbation of $3.5 \mathrm{ppbv}$ in spring, and an increase of $2.6 \mathrm{ppbv}$ for July (Cariolle et al., 2009). This last study and Huszar et al. (2010) study more especially focused on the assessment of plume sub-grid effects. They calculated that the nonlinear chemistry which takes place in the plume dispersion leads to a decrease of the aircraft and the shipping-induced ozone production, by 10 to $15 \%$ (free troposphere of Northern Hemisphere) and by 15 to $30 \%$ (surface ozone over the Eastern Atlantic), respectively.

For the first time, the combined effects of the three modes of transport and their respective influence on the current composition of the atmosphere have been recently investigated at the global scale, in the framework of the QUANTIFY project. A multi-model analysis based on 2000 preliminary road and aircraft (AERO2K 2002) emissions has been performed (Hoor et al., 2009). It provides a detailed interpretation of the chemical and transport processes involved in the 
ozone and $\mathrm{OH}$ current perturbations by the three transport modes, and the related radiative forcing, as well as an assessment of uncertainties due to the different models formulation. While differences were obtained in the magnitude of the impacts, similar results were simulated by the 6 global chemistry models involved (including LMDz-INCA), in terms of geographical patterns and respective contributions by the different transport modes. The mean results are also consistent with previous studies for aircraft and shipping, whereas the predicted road perturbation was found to be lower than previously reported in the literature. The authors attributed the differences to a significant under-estimation of the preliminary road emissions. Their study also highlighted that uncertainties between the models are larger in summer than in winter, with a maximum zonal mean ozone perturbation at $250 \mathrm{hPa}$ ranging from $3.5 \mathrm{ppbv}$ for LMDz-INCA model to $6 \mathrm{ppbv}$ for p-TOMCAT model, for July. In fact, the LMDz-INCA model is known to simulate relatively low tropospheric ozone production in summer compared to other models, due to particularly intense convection and associated dilution effect during this season.

While the impact of futures changes in anthropogenic emissions on background tropospheric ozone has been widely documented (e.g., for the most recent ones, Hauglustaine et al., 2005; Gauss et al., 2006; Niemeier et al., 2006; Granier et al., 2006; Eyring et al., 2005b, 2007; Stevenson et al., 2006; Søvde et al., 2007; Wu et al., 2008), only few of them specifically dealt with transport emissions, mainly because no reliable detailed emission scenarios for the next 100 years were available. Therefore, most of them are sensitivity rather than prediction studies. Moreover, as for present emissions, they focused on a specific transport mode. Niemeier et al. (2006) assumed road emissions in all regions of the world to be, on a capita basis, the same as in Europe and in the United-States. In the latter and most dramatic case, they calculated an increase by up to $50-100 \%$ (south Asia) of the surface ozone concentration compared to the present situation. Granier et al. (2006) analyzed the potential impact of changes in shipping routes in the Arctic region due to sea ice reduction induced by climate change. They found that the surface ozone concentration could increase during summertime to ozone levels comparable to the values currently observed in many industrialized regions of Northern Hemisphere. Eyring et al. (2007) analysed the impact of a constant annual growth rate of $2.2 \%$ of ship emissions up to 2030. They found a contribution of 2030 shipping emissions of up to 8 ppbv and $1.8 \mathrm{DU}$ for the annual mean nearsurface ozone and the ozone column, respectively. Gauss et al. (2006) investigated the effects of enhanced air traffic along polar routes, and of potential changes in cruising altitudes. They concluded that an enhanced use of polar routes would lead to a significant increase in the zonal mean ozone concentration at high Northern latitudes in summer, but to a negligible effect in winter. They also found that raising flight altitudes increases the ozone burden both in the troposphere and lower stratosphere, whereas lowering the flight altitude has a contrasting effect depending on the altitude (decrease of ozone production in the UTLS and increase below). Finally, Søvde et al. (2007) used a $2050 \mathrm{NO}_{\mathrm{x}}$ global aircraft emissions dataset from the EU project SCENIC. They calculated that the subsonic aircraft emissions could be responsible for an increase by up to $10-17 \mathrm{ppbv}$ of $\mathrm{O}_{3}$ in annual/July zonal mean in the UTLS of the Northern Hemisphere.

In addition to changes in emissions, the global tropospheric chemistry will be affected in the future by climate change (e.g., Hauglustaine et al., 2005; Isaksen et al., 2005; Brasseur et al., 2006; Liao et al., 2006; Murazaki and Hess, 2006; Stevenson et al., 2006; Grewe, 2007; Hedegaard et al., 2008; Wu et al., 2008). Most of the processes involved in the tropospheric chemistry depend notably on temperature, humidity and cloud cover. Because of a global temperature change, atmospheric transport and mixing properties in the atmospheric boundary layer will also be affected. The emission of $\mathrm{NO}_{\mathrm{x}}$ by lightning is also expected to increase with increasing convection. The atmospheric chemical reactions and photolysis rates will be modified because of changes in humidity and global radiation. Moreover, the liquid water content, the precipitation frequency and amount as well as the surface properties affect wet and dry deposition levels. All the previous studies showed that future climate change will lead to an increase in water vapor and $\mathrm{OH}$ at global scale. This increase in $\mathrm{OH}$ within the troposphere will contribute to a significant change in the typical life time of many species, since $\mathrm{OH}$ is participating in a large number of chemical reactions. As a result of enhanced water vapour, a decrease in future global ozone burden, but with positive and negative ozone changes according to altitude, season, model, and the reference year or the scenario are generally predicted (e.g., Wu et al., 2008, and references inside). Previous studies also showed that the changes in tropospheric ozone are not only dominated by tropospheric chemistry, but also by the stratospheric ozone budget and its flux into the troposphere, which could increase by 2100 because of climate change (e.g., Hauglustaine et al., 2005; Isaksen et al., 2005; Murazaki and Hess, 2006).Whereas all these previous studies focused on changes in the ozone background, the present study analyses the impact of climate change separately for the background ozone and for the ozone generated by the transport emissions. The hypothesis here is that the above-mentioned climate-induced physical and chemical atmospheric changes will also have a significant influence on the impact of the emissions from the transport sector.

Since the tropospheric impact of transport emissions is expected to show important changes in the next decades, because of changes in both emissions and climate, it is essential to assess such future changes, in order to implement adequate regulations and incentives. In this study, the LMDz-INCA model is used to study the impact of both present and future transport emissions, based on the QUANTIFY final updated emission datasets (Borken-Kleefeld et al., 2010). Our main 
objectives are (i) to quantify the contribution of each of the three sectors (road traffic, shipping and aircraft) to the ozone background concentrations, and (ii), for the first time, to evaluate the effects of future climate change on this transport impact. The following section describes the LMDz-INCA modeling system, focusing on its recent improvements (Sect. 2). The emissions, modeling and experiments are then presented (Sect. 3) and the simulation results are discussed (Sect. 4). Finally, conclusions are provided in Sect. 5.

\section{The Chemistry-Climate Model LMDz-INCA}

The global Climate Chemistry Model LMDz-INCA consists of the LMDz (Laboratoire de Météorologie Dynamique) General Circulation Model (Sadourny and Laval, 1984; Le Treut et al., 1994, 1998), coupled with the chemistry and aerosol model INCA (Interaction with Chemistry and Aerosols) in order to represent the chemistry of the troposphere (Hauglustaine et al., 2004; Folberth et al., 2006).

The version of the LMDz model used here (LMDz 4.0) is described in Hourdin et al. (2006). It has 19 hybrid levels on the vertical from the ground to $3 \mathrm{hPa}$ and a horizontal resolution of $2.5^{\circ}$ in latitude and $3.75^{\circ}$ in longitude $(96 \times 72$ grid cells). The large-scale advection of tracers is performed using the finite volume transport scheme of Van Leer (1977), as described in Hourdin and Armengaud (1999). The turbulent mixing in the planetary boundary layer is based on a secondorder closure model. In the present study, the Emanuel scheme (Emanuel, 1991, 1993) was used for convection. The primitive equations in $\mathrm{LMDz}$ are solved in 3 min time-step, large-scale transport of tracers is carried out every $15 \mathrm{~min}$ and physical processes are calculated at a 30 min time interval.

The INCA model is coupled on-line to the LMDz general circulation model. INCA considers the surface and 3$\mathrm{D}$ emissions, calculates dry deposition and wet scavenging rates, and integrates in time the concentration of atmospheric species with a time step of $30 \mathrm{~min}$. INCA uses a sequential operator approach, a method generally applied in chemistrytransport-models (Muller and Brasseur, 1995; Brasseur et al., 1998b; Wang et al., 1998; Poisson et al., 2000). In addition to the $\mathrm{CH}_{4}-\mathrm{NO}_{\mathrm{x}}-\mathrm{CO}-\mathrm{O}_{3}$ photochemistry representative of the tropospheric background (Hauglustaine et al., 2004), the non-methane hydrocarbon version of INCA used in this study (version NMHC.3.0) takes into account the photochemical oxidation pathways of non-methane hydrocarbons and non-methane volatile organic compounds from natural and anthropogenic sources, as well as their photochemical oxidation products. Unlike Cariolle et al. (2009), the plume effects from the transport emissions are not taken into account in the present study. For a more detailed description of the INCA-NMHC chemistry model, we refer to Folberth et al. (2006). A zonally and monthly averaged ozone climatology is prescribed above the tropopause $(150 \mathrm{hPa})$, based on $\mathrm{Li}$ and Shine (1995). This climatology is deliberately kept fixed at present-day values in all simulations in order to isolate the effects of tropospheric chemistry and climate change to changes in the stratospheric chemistry. Regardless the prescribed stratospheric ozone climatology, the stratosphere to troposphere exchanges are affected by changes in the vertical circulation across the tropopause.

The LMDz-INCA chemical results were compared to many other global CTMs or GCMs, and to observations during the international HTAP (Hemispheric Transport of Air Pollution) and ACCENT/PhotoComp (Atmospheric Composition Change: the European NeTwork of excellence) exercises. The related papers show a response (in term of sensitivity to emissions) of LMDz-INCA which is quite similar to the ensemble mean of the results for ozone (Stevenson et al., 2006). Comparisons with ozone surface network (Ellingsen et al., 2008) show a systematic positive bias for all the models, partly due to misrepresentation of $\mathrm{NO}_{\mathrm{x}}$ gradient close to the sources. Reidmiller et al. (2009) and Fiore et al. (2009) tried to discriminate the climatologic feature of ozone measured by the CASTNET (Clean Air Status and Trends Network; USA) and EMEP (European Monitoring and Evaluation Programme) networks before comparing with global models. LMDz-INCA showed in these studies a fairly good agreement for ozone with US stations. More recently, Jonson et al. (2010) compared 12 models involved in the HTAP experiment to ozone sonde measurements and concluded that the global models have far more difficulty in accurately reproducing ozone variability in the free troposphere. As stated by Shindell et al. (2006), all the global models show large under-estimates of Northern Hemisphere extra-tropical CO, while typically performing reasonably well elsewhere. An evaluation of the performance of the global chemistry transport and chemistryclimate models involved within the QUANTIFY project has also been performed (Schnadt et al., 2010), using observations from the long-term programme MOZAIC (Measurements of OZone, water vapour, carbon monoxide and nitrogen oxides by in-service AIrbus airCraft), as well as from the SPURT (Trace gas transport in the tropopause region), CONTRACE II (Convective Transport of Trace Gases into the Upper Troposphere over Europe) and TROCCINOX Tropical Convection, Cirrus and Nitrogen Oxides) campaigns. In accordance with the previous conclusions, the ozone concentrations are shown to be over-estimated at northern midlatitudes by the present version of LMDz-INCA and the other models, whereas $\mathrm{CO}$ is significantly underestimated by all models throughout the troposphere, at northern mid-latitudes and in the subtropics. No systematic bias is obtained for the $\mathrm{NO}_{\mathrm{x}}$ concentrations in the upper troposphere and lower stratosphere between LMDz-INCA simulations and the different observation campaigns. 


\section{Modelling set-up}

\subsection{Emissions}

The socioeconomic scenarios developed in the framework of the Intergovernmental Panel on Climate Change (IPCC) are commonly used as the reference to assess the future global anthropogenic emissions. All the related SRES (Special Report on Emission Scenarios) emission estimates (Nakicenovic and Swart, 2000) project a global increase in emissions of ozone precursors by 2050, mainly because of economic growth in developing countries. Three of them (A1B, A1T and B1) show a decrease in these emissions in Europe and North America. However, these global datasets, which are commonly used by the modellers' community to assess the impact of the emissions by the different sectors on global chemistry and climate, do not provide transport sectoral details. Furthermore, assumptions about quantitative and geographic changes in emissions are rapidly evolving with emissions regulations, technological and market progress, and potential for non-fossil fuels. Therefore, an update was required to assess how the impact from transport and from individual modes will be modified in future (Uherek et al., 2010). To this purpose, it is also of great importance to use realistic "present" and future emissions by other emission sectors, since the ozone sensitivity to traffic emissions substantially depends on background precursor concentrations. All the "present" and future transport emissions used in this study (Table 1) were especially provided by the FP6 QUANTIFY European project, as well as future non-traffic anthropogenic and the biomass burning emissions (www.pa.op.dlr.de/quantify/emissions). They consist in global files, with a resolution of $1^{\circ} \times 1^{\circ}$ longitude by latitude, for the years 2000 and 2050 and for two SRES marker scenarios (A1B and B1). The present non-traffic emissions are based on the latest release of the EDGAR 32FT2000 emission inventory for the year 2000 (van Aardenne et al., 2005; Olivier et al., 2005). For biomass burning, monthly means for the year 2000 were used, based on the Global Fire Emissions Database GFEDv2 (van der Werf et al., 2006) with multi-year (1997-2002) averaged data, using Andreae and Merlet (2001) emission factors, updated for $\mathrm{NO}_{\mathrm{x}}$. The effective injection height of biomass burning emissions into the atmosphere was taken into account with the emission heights as prescribed by Dentener et al. (2006).

The biogenic emissions were calculated for 2000 with the dynamical global vegetation model ORCHIDEE (Krinner et al., 2005), as described in Lathière et al. (2005). While these emissions might also show very important changes in future (e.g., Lathière et al., 2005, 2006), high uncertainties still remain about their future trends (Heald et al., 2009), so that no future global biogenic emission dataset can be provided for the different future IPCC scenarios. Therefore, they are fixed to the 2000 values in all our simulation experiments, such as oceanic emissions (Folberth et al., 2006).
The resulting QUANTIFY 2000 final emissions from road (Table 1) are 33\%, 50\% and 51\% higher than QUANTIFY preliminary ones (Hoor et al., 2009) for $\mathrm{NO}_{\mathrm{x}}$, $\mathrm{NMHC}$ and $\mathrm{CO}$, respectively. They are closer for $\mathrm{NO}_{\mathrm{x}}$, but still lower for $\mathrm{CO}$ and NMHC compared to previous assessments. For comparison, the road traffic emissions adopted by Matthes et al. (2005) and Niemeier et al. (2006) for NMHC and CO are about twice the emissions used in the present study. The emissions for ship traffic are the same as Hoor et al. (2009), and were reconstructed for QUANTIFY, based on Endresen et al. (2007). Only $\mathrm{NO}_{\mathrm{x}}$ emissions are considered in the present study. They represent a total $\mathrm{NO}_{\mathrm{x}}$ annual amount $(0.85 \mathrm{Tg} \mathrm{N})$ slightly higher but with very similar spatial distributions than AERO2K emission data.

The QUANTIFY transport emissions used in this study for $\mathrm{A} 1 \mathrm{~B}$ and $\mathrm{B} 1$ scenarios show very important changes in the future. Spatially, transport emissions shift in absolute amounts and relative shares from OECD countries to Asia, the Middle East and South America (Uherek et al., 2010). Road traffic emission fluxes strongly decrease at global scale, whereas a moderate (B1) to high (A1B) increase of the ship and aircraft emissions are expected by 2050 (Table 1). As shipping and aviation show strongest emissions in the future, increasing amounts of pollutants are emitted in the marine atmosphere and in the upper troposphere. As a result of changes in the use of the different transport modes, as well as in fuel composition, consumption and efficiency, transportinduced emissions of $\mathrm{NO}_{\mathrm{x}}$ decrease by $20 \%$ (A1B) and $55 \%$ (B1) until 2050, whereas NMVOC and CO emissions decline by a factor 4 (A1B) to 10 (B1). As a result from traffic and non-traffic emissions changes, the contributions of traffic to $\mathrm{NO}_{\mathrm{x}}, \mathrm{NMVOC}$ and $\mathrm{CO}$ total emissions decrease from $28 \%, 1.4 \%$ and $11 \%$ in 2000 to $26 \%, 0.34 \%$ and $2.8 \%$ and to $14 \%, 0.14 \%$ and $1.5 \%$ in 2050 for A1B and B1 scenarios, respectively. For aircraft emissions, an additional scenario (B1ACARE) based on excellent fuel efficiency is also investigated (Table 3 ).

\subsection{The perturbation approach}

A small perturbation approach is used to assess the impact of transport emissions on global chemistry. For all studied scenarios, a reference simulation is first performed with all emissions. Then, the road traffic, ship and aircraft emissions are separately reduced by $5 \%$ in 3 additional simulations. The total impact of transport emissions is calculated by adding the three perturbations rather than by simulating an additional perturbation run for all transport emissions. Sensitivity tests performed with LMDz-INCA for 2000 emissions clearly demonstrated that the effect on ozone of small emission reductions is additive: the perturbations on the ozone column and the zonal mean ozone induced by a $5 \%$ reduction of all transport emissions differ by less than $0.3 \%$ compared to the sum of the 3 perturbations due to a $5 \%$ reduction of each transport mode. The small perturbation 
Table 1. Global emissions and corresponding modelling experiments.

\begin{tabular}{|c|c|c|c|c|c|}
\hline $\begin{array}{l}\text { Year- } \\
\text { scenario }\end{array}$ & $\begin{array}{l}\text { Emission } \\
\text { source }\end{array}$ & $\begin{array}{r}\mathrm{NO}_{\mathrm{x}} \\
\mathrm{Tg}(\mathrm{N}) \mathrm{yr}^{-1}\end{array}$ & $\begin{array}{r}\mathrm{CO} \\
\mathrm{Tg}(\mathrm{CO}) \mathrm{yr}^{-1}\end{array}$ & $\begin{array}{r}\text { NMHC } \\
\operatorname{Tg}(\mathrm{C}) \mathrm{yr}^{-1}\end{array}$ & Experiments \\
\hline \multirow[t]{9}{*}{2000} & Road traffic & 9.1 & 110.2 & 11.3 & $A, D$ \\
\hline & Ships & 4.4 & 1.4 & 0.3 & \\
\hline & Aircraft & 0.85 & & & \\
\hline & Total transport & 14.3 & 111.6 & 11.7 & \\
\hline & Non-traffic & 18.7 & 344.9 & 79.3 & \\
\hline & Biomass burning & 10.2 & 507.5 & 28.8 & \\
\hline & Biog., soil, ocean & 8.7 & 20 & 721.8 & \\
\hline & Total & 51.9 & 984.0 & 841.6 & \\
\hline & Transport contribution (\%) & $28 \%$ & $11 \%$ & $1.4 \%$ & \\
\hline \multirow{9}{*}{$2050-\mathrm{B} 1$} & Road traffic & 0.5 & 4.1 & 0.5 & $\mathrm{~B}$ \\
\hline & Ships & 5.0 & 3.4 & 0.6 & \\
\hline & Aircraft & 1.1 & & & \\
\hline & Total transport & 6.6 & 7.5 & 1.15 & \\
\hline & Non-traffic & 27.6 & 274.5 & 95.9 & \\
\hline & B. burning & 3.8 & 184.0 & 13.1 & \\
\hline & Biogenic, soil, ocean & 8.7 & 20 & 721.8 & \\
\hline & Total & 46.6 & 486.0 & 831.9 & \\
\hline & Transport contribution (\%) & $14 \%$ & $1.5 \%$ & $0.1 \%$ & \\
\hline \multirow[t]{9}{*}{$2050-\mathrm{A} 1 \mathrm{~B}$} & Road traffic & 1.7 & 26.3 & 1.7 & $\mathrm{C}, \mathrm{E}, \mathrm{F}$ \\
\hline & Ships & 8.6 & 5.4 & 1.2 & \\
\hline & Aircraft & 3.3 & & & \\
\hline & Total transport & 13.7 & 31.7 & 2.9 & \\
\hline & Non-traffic & 21.8 & 666.9 & 98.9 & \\
\hline & B. burning & 8.3 & 403.8 & 23.7 & \\
\hline & Biogenic, soil, ocean & 8.7 & 20.0 & 721.8 & \\
\hline & Total & 52.4 & 1122.4 & 847.3 & \\
\hline & Transport contribution (\%) & $26 \%$ & $2.8 \%$ & $0.3 \%$ & \\
\hline
\end{tabular}

approach minimizes non-linearity in atmospheric chemical effects, which would occur by setting the respective emissions to zero. Furthermore, a small reduction in emissions is expected to be more realistic than a total decline.

Despite the non-linear character of the ozone perturbation, the $100 \%$ up-scaled perturbations (multiplied by a factor 20) are displayed on the figures, in order to better compare with the results of Hoor et al. (2009) and other previous studies using such up-scaling. In order to quantify the non-linear effects, and to compare with previous studies using a total removal of emissions, a $100 \%$ decline of 2000 emissions was also simulated separately for each transport mode. Results (not shown) indicate that the total removal of transport emissions induces an $8 \%$ higher transport-induced ozone burden perturbation, compared to the small perturbations subsequently rescaled to $100 \%$ (4.4\%, $5.7 \%$ and $15.6 \%$ higher perturbations for shipping, aircraft and road traffic, respectively). At regional scale, differences can reach up to $15 \%, 18 \%$ and $60 \%$ in zonal mean for road (boundary layer of Northern Hemisphere), aircraft (UTLS of Northern Hemisphere) and shipping (boundary layer of Northern Hemisphere), respectively. These results emphasize the need to always compare perturbations from a same modelling perturbation approach, as proposed in our study, and discussed in Grewe et al. (2010).

\subsection{Experiments}

\subsubsection{Emission change experiments}

In order to assess the impact of 2000 to 2050 changes in emissions by each transport mode on the tropospheric chemical composition, six sets of experiments (Table 2) were performed for present, and future (A1B and B1 scenario) 
Table 2. Set-up of the LMDz-INCA modelling experiments. The A to C experiments correspond to nudged simulations (2002-2003, ECMWF meteorology) and the D to F experiments to 10-yrs climatic simulations (GCM mode). For each of these runs, "perturbation" runs have been performed, by applying a 5\% emission reduction to each of the three transport modes separately (Cases A to $\mathrm{C}$ ) and/or simultaneously (Cases D to F). The first and the first three years have been discarded as the spin-up of the model, for nudged and climatic runs, respectively.

\begin{tabular}{lllrlrll}
\hline Case & Mode (period) & $\begin{array}{l}\text { Surface } \mathrm{CH}_{4} \\
\text { ppbv }\end{array}$ & $\begin{array}{r}\text { Transport and } \\
\text { other anthrop. } \\
\text { emissions }\end{array}$ & SST \& Sea ice & $\begin{array}{l}\mathrm{CO}_{2} \\
\text { ppmv }\end{array}$ & $\begin{array}{l}\mathrm{CH}_{4} \\
\text { ppbv }\end{array}$ & $\begin{array}{l}\mathrm{N}_{2} \mathrm{O} \\
\text { ppbv }\end{array}$ \\
\hline A & Nudged (2002-2003) & 1760 & 2000 & ECMWF & 368 & 1760 & 316 \\
B & Nudged (2002-2003) & 1880 & B1 2050 & ECMWF & 368 & 1760 & 316 \\
C & Nudged (2002-2003) & 2400 & A1 B 2050 & ECMWF & 368 & 1760 & 316 \\
D & Climatic (1995-2004) & 1760 & 2000 & HadGEM1 & 368 & 1760 & 316 \\
E & Climatic (1995-2004) & 2400 & A1 B 2050 & HadGEM1 & 368 & 1760 & 316 \\
F & Climatic (2045-2054) & 2400 & A1 B 2050 & HadGEM1 & 532 & 2400 & 350 \\
\hline
\end{tabular}

emission datasets described in Table 1. Nudged runs over the 2002-2003 period, using the ECMWF operational winds and temperature fields, were performed, which allows an evaluation of the performance of the different global chemistry models involved in QUANTIFY (Schnadt et al., 2010). The year 2002 was discarded to allow for the spin-up of the model and the year 2003 was analyzed. As described in Jourdain and Hauglustaine (2001), the Emanuel convection parameterization was used, which leads to a global annual $\mathrm{NO}$ production from lightning activity of about $5 \mathrm{Tg} \mathrm{NO}_{\mathrm{x}}$ $\mathrm{N}$, which is similar to other studies (e.g., Lee et al., 1997; Prather et al., 2001).

In addition to the base runs reported in Table 2, corresponding 5\% (and 100\%) perturbed runs were also performed. To account for the corresponding changes in $\mathrm{CH}_{4}$ emissions, the $\mathrm{CH}_{4}$ concentrations were prescribed as surface boundary conditions in the INCA model, on the basis of time-varying tropospheric mean mixing ratio of methane provided by the ENSEMBLES project (Hewitt and Griggs, 2004). A monthly and latitudinal variability of $\mathrm{CH}_{4}$ surface concentrations, based on observations from the AGAGE database was applied to these averaged mean ratios to account for the natural variability (Jöckel et al., 2006). An additional set of unperturbed/perturbed B1 scenario was also simulated in order to assess the impact of possible mitigation options for aircraft, by reducing the $\mathrm{NO}_{\mathrm{x}}$ aircraft emissions according to ACARE (Advisory Council for Aeronautics Research in Europe; http://www.acare4europe.org/) targets for year 2050, as described in Table 3. These emission change experiments do not consider any climate change, which effects are further analyzed through the climate change experiments, described in the following section.

\subsubsection{Climate change experiments}

Two 10 year periods (1995-2004 and 2045-2054) were simulated with the LMDz-INCA model in order to study the impact of climate change (Table 2). The first three years were discarded as the spin-up of the model and the 7 remaining years were averaged for each month of the year. Like the emissions change experiments, the impact of the transport emissions is assessed through a small perturbation approach (5\% emission reduction). However, for computing sake, the perturbation is simultaneously applied to all the transport modes, rather than to each mode separately.

Firstly, the 2000 emissions were simulated in a present climate (Case D). Then, for both 10 year periods, the chemical emissions were fixed at 2050 level, in order to isolate the effect of climate change only (Cases $\mathrm{E}$ to $\mathrm{F}$ ). The 2050 emissions from the A1B scenario were used. $\mathrm{CO}_{2}$, $\mathrm{CH}_{4}$ and $\mathrm{N}_{2} \mathrm{O}$ green house gas concentrations were fixed in the LMDz model to $368 \mathrm{ppmv}, 1760 \mathrm{ppbv}$ and $316 \mathrm{ppbv}$ and to $532 \mathrm{ppmv}, 2400 \mathrm{ppbv}$ and $350 \mathrm{ppbv}$, for "present" (2000) and future (2050) climates, respectively, on the basis of IPCC (2001). Transient climate simulation outputs from the Hadley Centre Global Environmental Model version 1 (HadGEM1) were used for sea-surface temperatures and sea ice (Stott et al., 2006). A 10-year averaging has been performed for each month separately to drive the LMDz model, over the 1995-2004 and 2045-2054 periods.

The difference between $\mathrm{D}$ and $\mathrm{E}$ base runs gives an estimate of the impact of 2000-2050 change in emissions in a present climate, whereas the impact of climate change is calculated from the difference between cases $\mathrm{E}$ and $\mathrm{F}$. The $\mathrm{E}$ and $\mathrm{F}$ perturbed runs $(5 \%$ reduction in transport emissions) provide an estimate of the impact of 2050 emissions by the transport sector in a present and future climate, respectively. Finally, the change between the two latter impacts gives an estimate of the effect of climate change on the 
Table 3. Present 2000 and future (2050) global $\mathrm{NO}_{\mathrm{x}}$ emissions by aircraft (and all transport modes).

\begin{tabular}{llllr}
\hline Year & Scenario & Traffic Demand & $\begin{array}{l}\text { Aircraft technology } \\
\text { description }\end{array}$ & $\begin{array}{r}\mathrm{NO}_{\mathrm{x}} \text { in } \mathrm{Tg}_{\mathrm{N}} \mathrm{yr}^{-1} \\
\text { (all transports) }\end{array}$ \\
\hline 2000 & \multirow{2}{*}{ A1B(i) } & $\begin{array}{l}\text { Current } \\
\text { GDP driven }\end{array}$ & $\begin{array}{l}\text { Current } \\
\text { Moderate to good fuel efficiency, } \\
\text { moderate NOx improvements }\end{array}$ & $\begin{array}{r}0.85(14.1) \\
3.33(14.29)\end{array}$ \\
\hline \multirow{2}{*}{ B1 } & GDP driven but intra-regional \\
& growth decoupled from GDP & $\begin{array}{l}\text { Good fuel efficiency } \\
\text { improvements }\end{array}$ & $1.05(6.6)$ \\
& & $\begin{array}{l}\text { GDP driven but intra-regional } \\
\text { growth decoupled from GDP }\end{array}$ & $\begin{array}{l}\text { Excellent fuel efficiency and } \\
\text { NOx improvements: ACARE targets } \\
\text { achieved in 2020 and continuing } \\
\text { improvements beyond 2020. }\end{array}$ & $0.70(6.2)$ \\
\hline
\end{tabular}

impact of emissions by the transport sector between 2000 and 2050. It must be emphasized here that the present (experiments $\mathrm{A}$ to $\mathrm{E}$ ) and future (experiment F) climates are fixed using HadGEM1 simulation outputs, and therefore, that the changes in the tropospheric chemistry simulated in this study do not feedback on climate.

\section{Results and discussion}

\subsection{Impact of present-day transport emissions on the global tropospheric chemistry}

In this section, we assess the impact of present (2000) emissions by each of the three transport modes on tropospheric ozone from a 5\% perturbation approach, based on our base run inventory (Table 1). The results are illustrated for July, which is the most documented month in the literature. The ozone perturbations due to 2000 transport emissions (Case A) are shown in Fig. 1. The perturbation of the tropospheric ozone column by all transport emissions is characterized by a strong hemispheric difference, with maximum effects in the Northern Hemisphere. A maximum impact is simulated over Europe and the Central Atlantic, reaching up $5 \mathrm{DU}$ for the $100 \%$ up-scaled perturbation (instead of $4.5 \mathrm{DU}$ for LMDz-INCA preliminary simulations, Hoor et al., 2009). The zonal mean ozone mixing ratio perturbation shows a maximum of $7 \mathrm{ppbv}$ in the upper troposphere/lower stratosphere in the northern extra-tropics. At the surface, the total transport perturbation is also mainly concentrated over the Northern Hemisphere, with maxima of 8 ppbv over both land (over the eastern and western coasts of the US and over Arabia) and sea (Mediterranean Sea) regions. Due to titration effect (Eyring et al., 2007), a slight ozone decrease is predicted under high $\mathrm{NO}_{\mathrm{x}}$ conditions over the North Sea.

Future changes in ozone production by the transport sector will strongly depend on the respective contributions of the different transport modes (see for instance, Dahlmann et al., 2009). Therefore, it is important in terms of mitigation options, to quantify the present and the future respective contributions of each of them. Figures 2, 3 and 4 show the relative contribution of each transport modes to the total transport-induced perturbation of the ozone tropospheric column, surface mixing ratio and zonal mean mixing ratio, respectively. The role of present-day road emissions is highly dominant in comparison to the two other modes. It reaches up $85 \%$ over Asia, $75 \%$ over the US and $70 \%$ over Europe for the tropospheric column perturbation (Fig. 2). The relative contribution of road emissions to the ozone mixing ratio peaks in the free troposphere in both hemispheres, with a pronounced seasonal cycle in the northern extra-tropics, and a maximum in July. During summer, the boundary layer mixing and convective transport into the free troposphere of the road traffic emissions are more vigorous (Hoor et al., 2009). This explains the obtained seasonal cycle of the perturbation and why a high impact of road emissions is not only predicted in the boundary layer over land, where it accounts for up to $95 \%$ of the total perturbation (Fig. 3), but also in the free troposphere (Fig. 4). Road traffic emissions account for up to $70 \%$ and $60 \%$ of the total zonal mean perturbation in the mid and northern high troposphere. North of $40^{\circ} \mathrm{S}$, the contribution of shipping emissions to the ozone column and to the zonal mean mixing ratio in the mid $(<800 \mathrm{hPa})$ and upper troposphere is lower than for road traffic emissions (Fig. 4). In low troposphere, shipping emissions are the major perturbation in both hemispheres (i.e. $>50 \%$ and $>40 \%$ of the total transport perturbation on the ozone column and on the zonal mean mixing ratio, respectively), with a maximum share of $60 \%$ at the equator. The impact is mainly located over marine regions, islands and coastal areas, where it represents up to $95 \%$ of the total transport-induced perturbation on the surface ozone mixing ratio (Fig. 3). Despite much lower emission levels than for ships and road traffic, $\mathrm{NO}_{\mathrm{x}}$ emitted by aviation also lead to a significant increase of ozone in the upper troposphere. This is due to higher 
a. Zonal mean ozone $\left(\mathrm{ppb}_{\mathrm{v}}\right)$
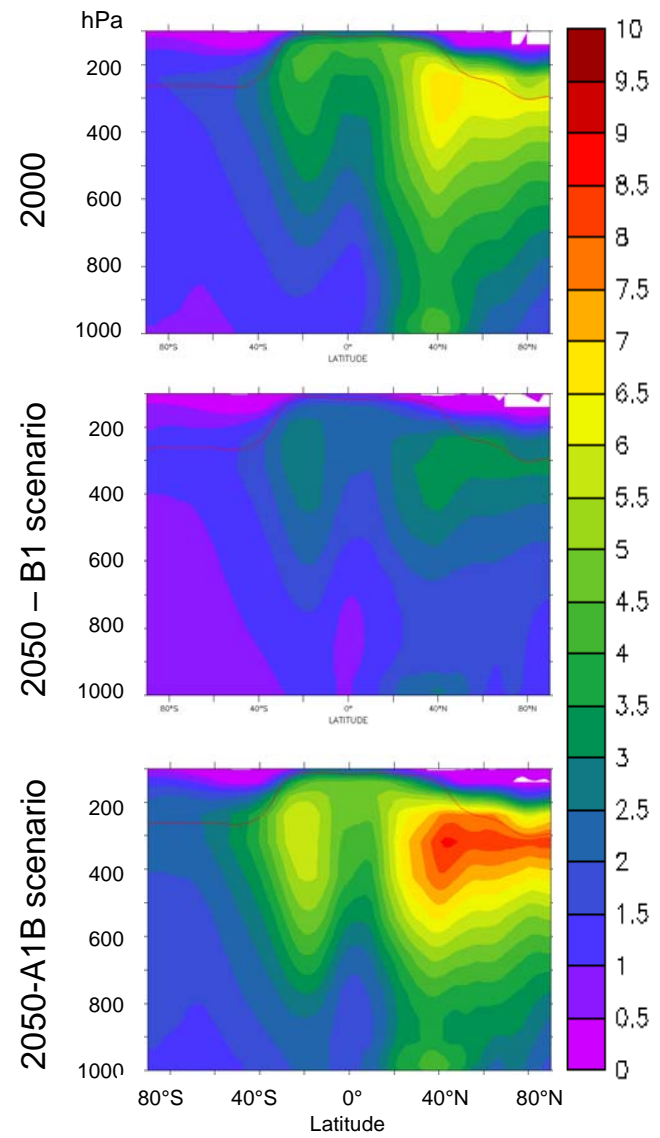

b.Tropospheric ozone column (DU)
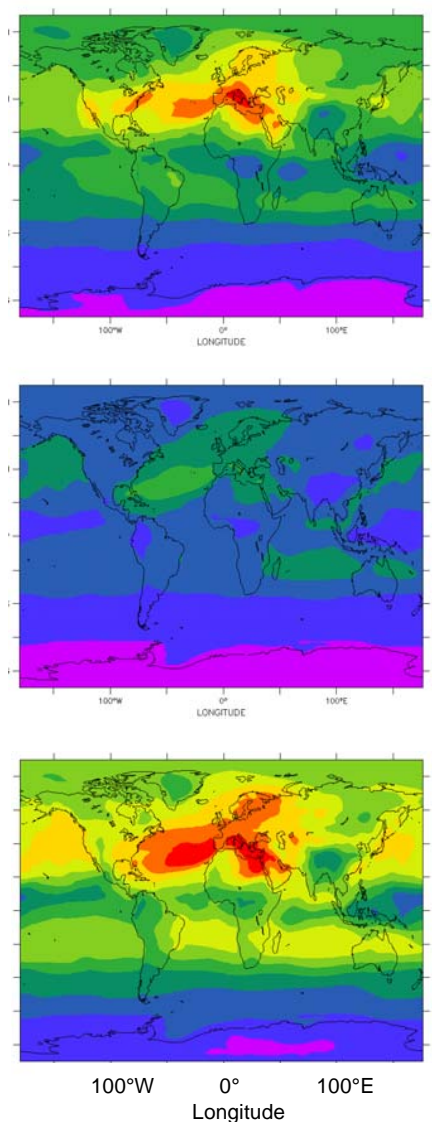

c. Surface ozone $\left(\mathrm{ppb}_{\mathrm{v}}\right)$

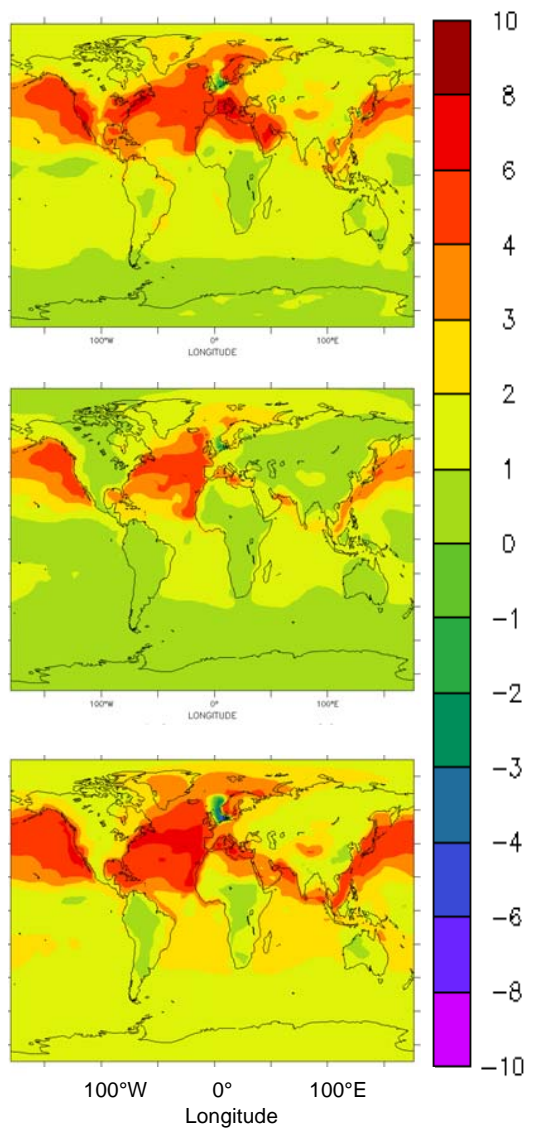

Fig. 1. Total (aircraft, shipping and road traffic) transport up-scaled (5\% decrease effect $\times 20)$ perturbation in July for (a) zonal mean ozone $\left(\Delta \mathrm{ppb}_{v}\right)$, (b) tropospheric ozone column ( $\Delta$ DU), and (c) surface ozone $\left(\Delta \mathrm{ppb}_{v}\right)$, due to 2000 (A experiment), $2050 \mathrm{~B} 1 \mathrm{scenario}$ (B experiment) and 2050 A1B scenario (C experiment) emissions (the solid line on plots a indicates the tropopause).

ozone production efficiency than for the two other modes. The LMDz-INCA results for QUANTIFY aircraft emissions $\left(0.85 \mathrm{Tg}(\mathrm{N}) \mathrm{yr}^{-1}\right)$ are qualitatively and quantitatively close to those obtained for AERO2K emissions $\left(0.67 \mathrm{Tg}(\mathrm{N}) \mathrm{yr}^{-1}\right)$. The maximum perturbation mainly lies from 250 to $350 \mathrm{hPa}$ and $40^{\circ}$ to $70^{\circ} \mathrm{N}$, which corresponds to the North Atlantic Flight Corridor. Maximum perturbations of 2.5 and $2.4 \mathrm{ppbv}$ are respectively obtained in the UTLS of Northern Hemisphere, corresponding to $40 \%$ of the total transport perturbation in this area for July (Fig. 4). The impact in the lower troposphere $(<10 \%$ in zonal mean; Fig. 4$)$ and at the surface $(<15 \%$ over most of the globe; Fig. 3$)$ is low, except over Northern Asia, where it reaches up 30\% of the total surface perturbation by the three transport modes.

Figure 5 shows the ozone perturbation to the combined emissions from the different transport sectors. As for Fig. 1, the $100 \%$ up-scaled perturbations are displayed to better allow the comparison with Hoor et al. (2009). The perturbation ranges from $4 \%$ to $9 \%$ (Western Europe, Indian ocean, Southern Asia) and 10\% (Mexico Gulf) for the ozone col- umn, North of $20^{\circ} \mathrm{S}$ in July (Fig. 5), and throughout the year (not shown). In the southern extra-tropics, the perturbation is less than $5 \%$. The relative perturbation to the zonal mean ozone ranges from $4 \%$ to $8 \%$ in the UTLS in the Northern Hemisphere, and up to $13 \%$ in the boundary layer. The perturbation in the Southern Hemisphere is about 4-5\% in the low and middle troposphere (below $500 \mathrm{hPa}$ ) and of $2-3 \%$ above.

Hereafter, we compare our simulations results from a total removal of emissions from each transport mode (not shown) to previous studies using the same approach. As for our 5\% road emission perturbation run, the total removal of the road traffic emissions in the LMDz-INCA model leads to a maximum ozone perturbation in July, when they are responsible for an increase in the zonally averaged ozone of up to $7 \%$ in the boundary layer, $5 \%$ at $500 \mathrm{hPa}$ and $4 \%$ at $300 \mathrm{hPa}$, in the Northern Hemisphere. These results are consistent with Niemeier et al. (2006) who reported very similar spatial patterns, and slightly higher perturbations (up to $10 \%$, $6 \%$ and 5\%, respectively). Matthes et al. (2007) results are 

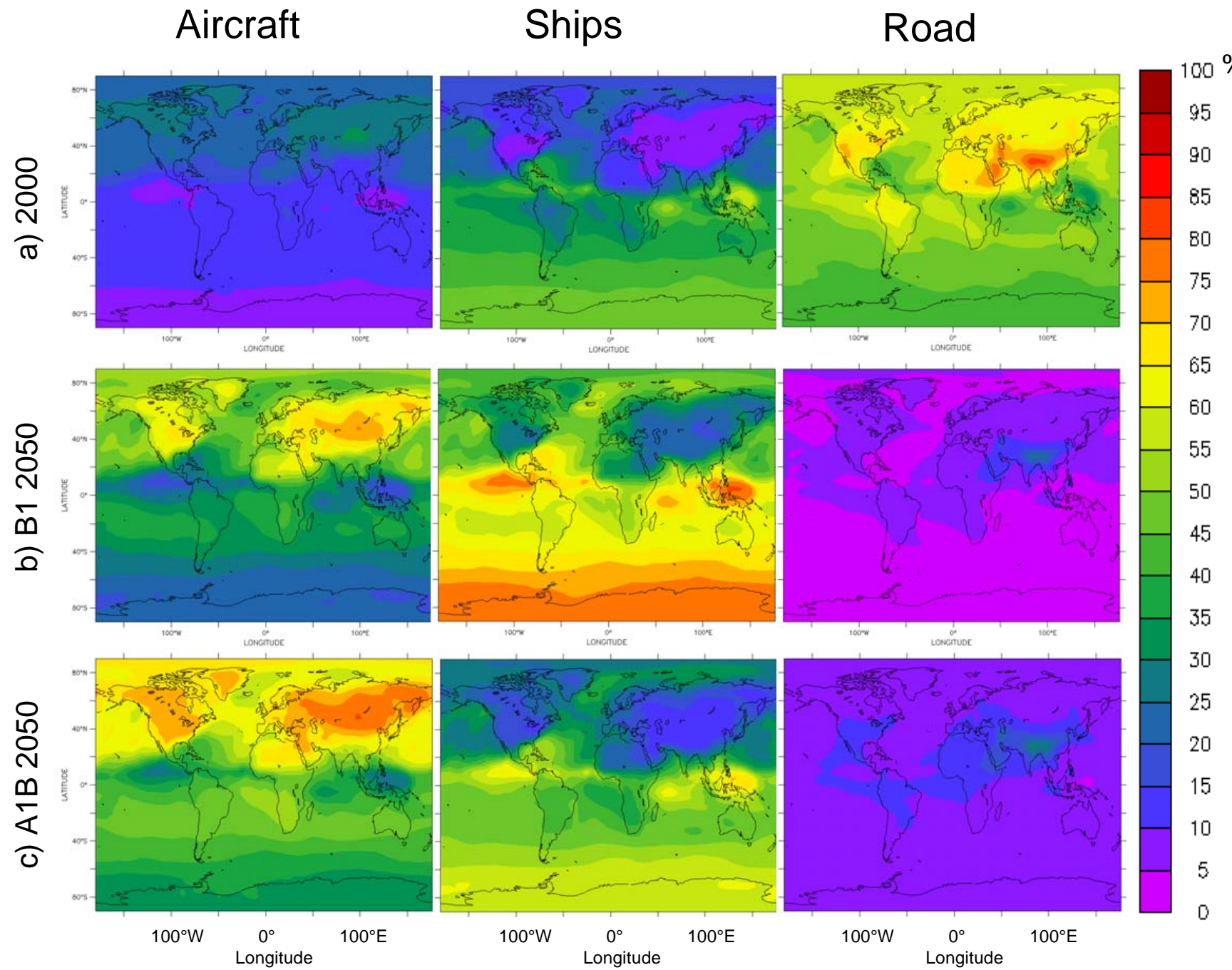

Fig. 2. Respective contribution (\%) of each transport mode to the tropospheric ozone column change due to transport in July, for 2000 (A experiment) and 2050 (B1 and A1B scenarios; B and C experiments, respectively) emissions.

somewhat larger (up to $12 \%, 8 \%$ and $6 \%$, respectively). As previously mentioned, both previous studies used similar total road emissions for $\mathrm{NO}_{\mathrm{x}}$, but higher amounts for $\mathrm{CO}$ and NMHC than in the present work. Removing all shipping emissions leads to a decrease in the near-surface zonal mean of up to $3.2 \mathrm{ppbv}$ and $1.8 \mathrm{ppbv}$ at northern mid-latitudes for July and annual zonal means, respectively. A relative contribution up to 5\% (over Asia) and 50\% (over the North Pacific) to the ozone column and surface ozone are calculated, respectively. These results are of the same order of magnitude than in Eyring et al. (2007): using 30\% lower $\mathrm{NO}_{\mathrm{x}}$ emissions from shipping, this multi-model study reported an increase in near-surface annual and zonal mean $\mathrm{O}_{3}$ up to $1.3 \mathrm{ppbv}$, ranging from 1.0 (LMDz-INCA) to $1.9 \mathrm{ppbv}$, according to the model. They obtained a maximum increase of about $12 \mathrm{ppbv}$ (modeled ensemble mean) over the North Atlantic for July, whereas we obtain up to 8 ppbv and 9 ppbv over the Atlantic and Pacific oceans, respectively. Our results are closer to
Dalsoren et al. (2009), who calculated a contribution of the ship emissions of up to 5-6\% to the tropospheric ozone column (over the North Atlantic) and up to $40 \%$ to the surface ozone (over the North Pacific) for 2004 shipping emissions. As previously mentioned, Dalsoren et al. (2009) also used updated QUANTIFY emissions, but for 2004 (10\% more $\mathrm{NO}_{\mathrm{x}}$ than in 2000 QUANTIFY emissions). In both cases, the Northern Pacific is the most impacted region, whereas Eyring et al. (2007) obtained a much lower impact over the Pacific $(<4$ ppbv for the ensemble mean) compared to the Atlantic (up to $12 \mathrm{ppbv}$ ). This can explain the lower surface zonal mean $\mathrm{O}_{3}$ perturbation ( $1.3 \mathrm{ppbv}$ against $1.8 \mathrm{ppbv}$ ) obtained in this previous study, which was shown to underestimate the shipping emissions over the Pacific ocean. We showed previously that the impact of aircraft emissions on tropospheric ozone, as simulated by the LMDz-INCA model (5\% perturbation runs) using QUANTIFY and AERO2K emissions data and two different $\mathrm{NO}_{\mathrm{x}}$ lightning productions, are very 

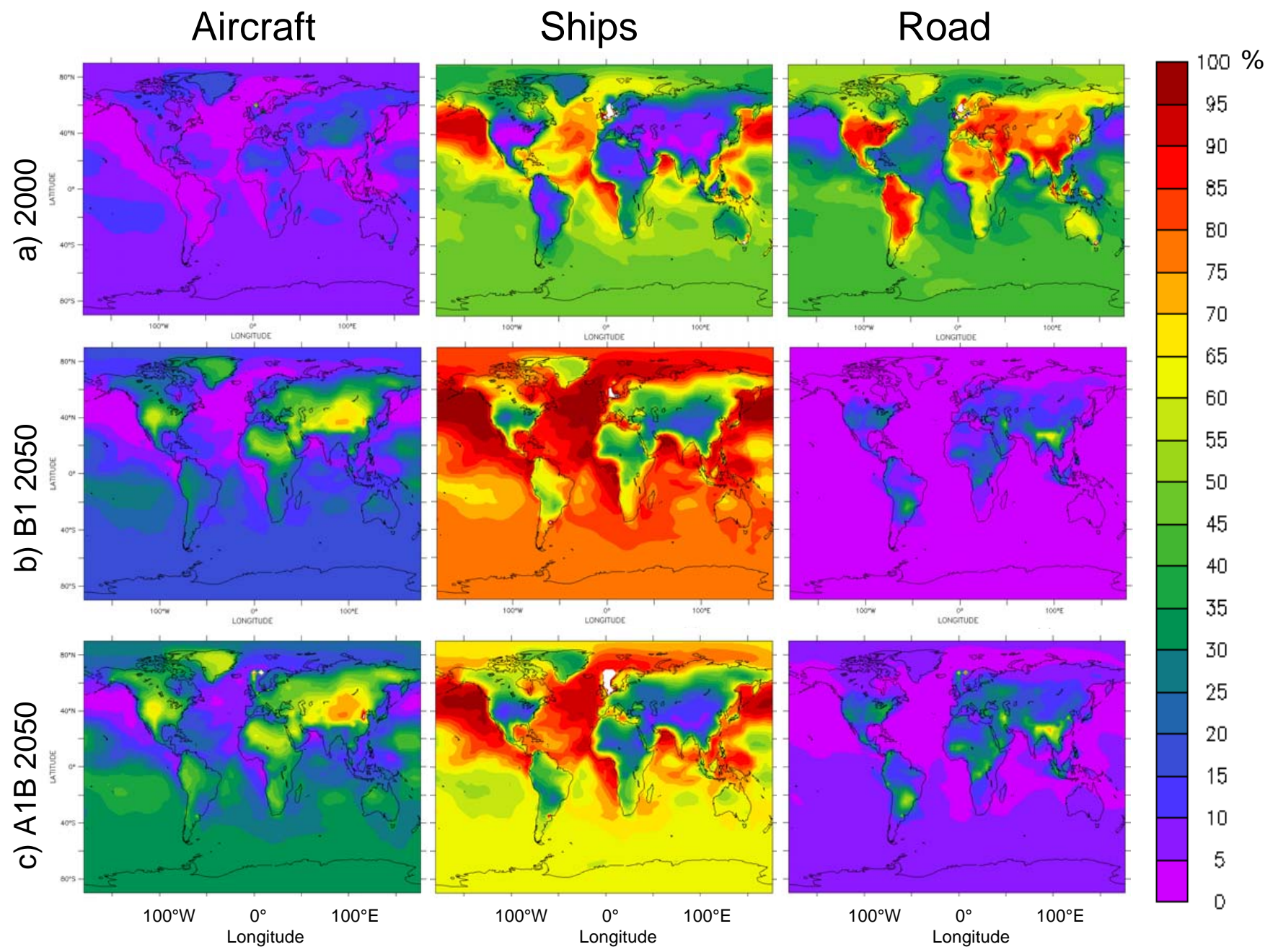

Fig. 3. Same as Fig. 2 for surface ozone mixing ratio.

similar, but located in the lower range of the perturbations reported in Hoor et al. (2009) for July. Our results for a total removal of QUANTIFY aircraft emissions lead to similar results, with a maximum zonal-mean perturbation of $2.6 \mathrm{ppbv}$ in the UTLS of Northern Hemisphere, which is significantly lower than the perturbation of $6 \mathrm{ppbv}$ obtained by Gauss et al. (2006). One reason for such discrepancies is the strong dilution effect due to particularly high convection and mixing calculated by the LMDz-INCA model in summer, which induces lower ozone perturbations from aircraft and shipping compared to other models, and a maximum in spring.

\subsection{0 to 2050 changes in the impact of transport emissions}

In this section, we describe the impact of the future changes in anthropogenic emissions on the role of the transport sector on the global tropospheric chemistry. The simulations have been performed for two different scenarios (Table 2). As previously, the $100 \%$ up-scaled perturbations are shown (see
Sect. 3.2). Except where stated, the results in this section are mainly discussed in terms of 2000 to 2050 relative change in the transport-induced ozone perturbation rather than in terms of absolute perturbation. The impact of emissions from each transport mode, and from all transport emissions are firstly reported. The sensitivity of the results to possible mitigation options is then discussed.

\subsubsection{A1B and B1 emission scenarios}

Based on the QUANTIFY future emissions, we assume a high reduction of road emissions, and a moderate (B1 scenario) to high (A1B scenario) increase of ship and aircraft emissions in 2050. As a consequence, the contribution of road traffic to the $\mathrm{O}_{3}$ column perturbation drastically decreases in 2050, accounting for less than $15 \%$ of the total transport perturbation over most of the globe, for both scenarios (Fig. 2). Ship emissions become the predominant contribution to the $\mathrm{O}_{3}$ column perturbation in the Southern Hemisphere, especially for the B1 scenario, for which 


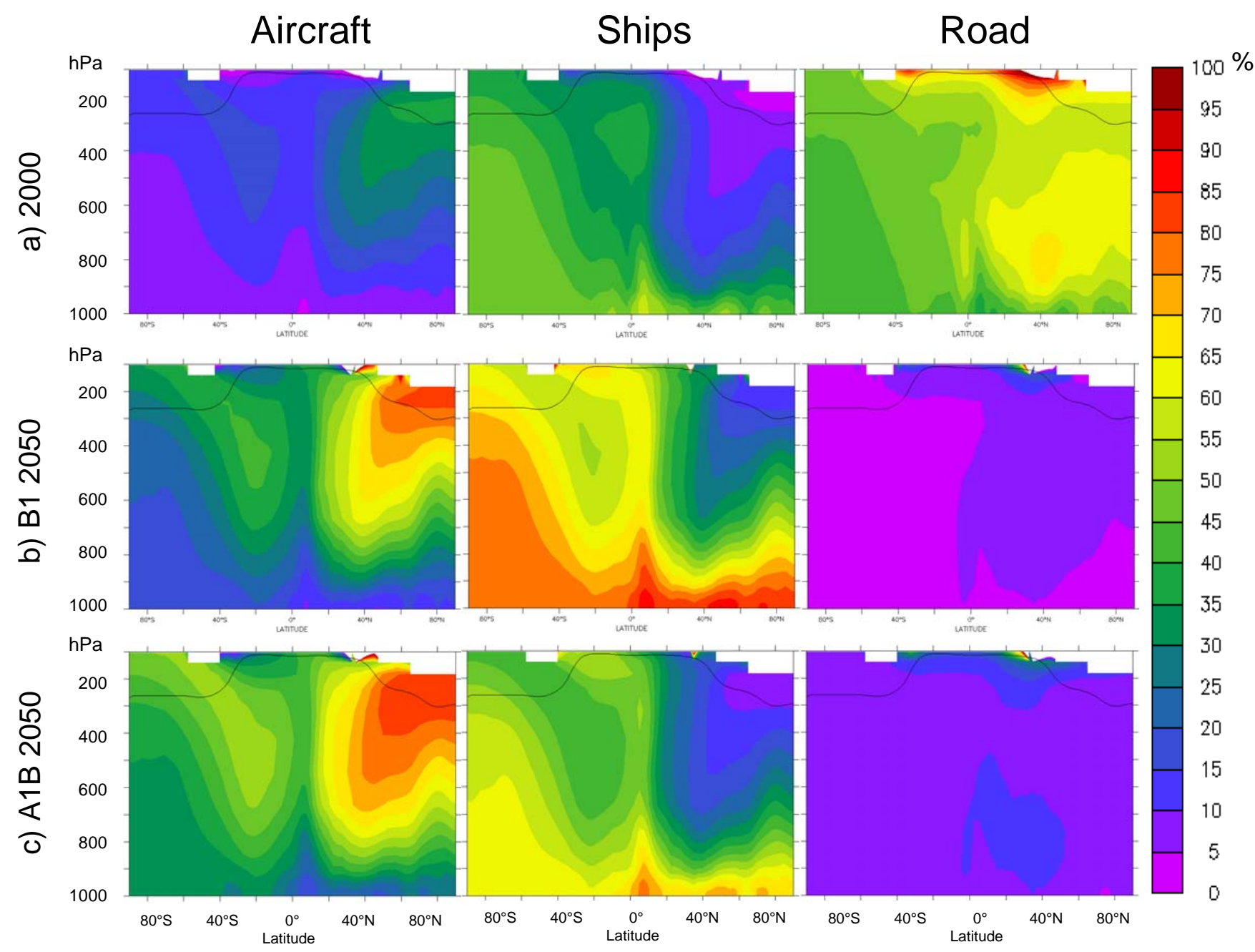

Fig. 4. Same as Fig. 2 for zonal mean ozone mixing ratio. The solid line indicates the tropopause.

it contributes up to $85 \%$ to the overall perturbation (Indonesia). Ships also have a predominant contribution in the lower troposphere in the Northern Hemisphere (Fig. 4). Their influence remains mainly located over marine regions, whereas aircraft have the strongest impact on ozone in the continental boundary layer (Fig. 3). Nevertheless, in the case of the B1 scenario, the impact of shipping on surface ozone extends more inside the continents, because of the synoptic transport of ozone and its precursors inland. The surface ozone perturbation due to ship emissions in the most affected coastal regions increases from about 2 ppbv in 2000 to 3 ppbv. In both future scenarios, subsonic aviation becomes the major ozone perturbation in the Northern Hemisphere, by contributing up to $70 \%$ and $75 \%$ to the total transport perturbation over the US, and up to $80 \%$ and $85 \%$ over continental Asia, for B1 and A1B scenarios, respectively (Fig. 2).

In the case of the B1 scenario, the decreased transport emissions lead to a significant reduction (by roughly 50\%) of the ozone perturbation throughout the troposphere in 2050 (Figs. 1 and 5). At the surface, an even more pro- nounced decrease of the perturbation is simulated over land, due to the drastic reduction in road emissions. The total (up-scaled) surface ozone perturbation over Western Europe drops from $6 \mathrm{ppbv}$ to less than $2 \mathrm{ppbv}$ (Fig. 1c). For the same reason, the combined impact of traffic decreases over the oceans, despite a slight increase in ship emissions (from 4.39 to $5.05 \mathrm{Tg}(\mathrm{N}) \mathrm{yr}^{-1}$ ). Despite similar total $\mathrm{NO}_{\mathrm{x}}$ transport emission in 2050 compared to 2000 (i.e., 14.3 against $\left.14.1 \mathrm{Tg}(\mathrm{N}) \mathrm{yr}^{-1}\right)$, the A1B scenario leads to an increase of the impact of transport on ozone by up to $+30 \%$ and $+50 \%$ in the Northern and Southern Hemispheres, respectively (Figs. 1 and 5). The increase is even more pronounced in the UTLS region in the Northern Hemisphere. This is mainly due to a high increase in aircraft emissions (from 0.85 to $3.3 \mathrm{Tg}(\mathrm{N}) \mathrm{yr}^{-1}$ ), and to their high ozone production efficiency. In the lower troposphere, in the Northern Hemisphere, the relative perturbation increases by $2050 \mathrm{ac}-$ cording to scenario $\mathrm{A} 1 \mathrm{~B}$, but to a lesser extent than in the upper troposphere, and mainly at high latitudes (above $50^{\circ} \mathrm{N}$ ). 
Tropospheric ozone column
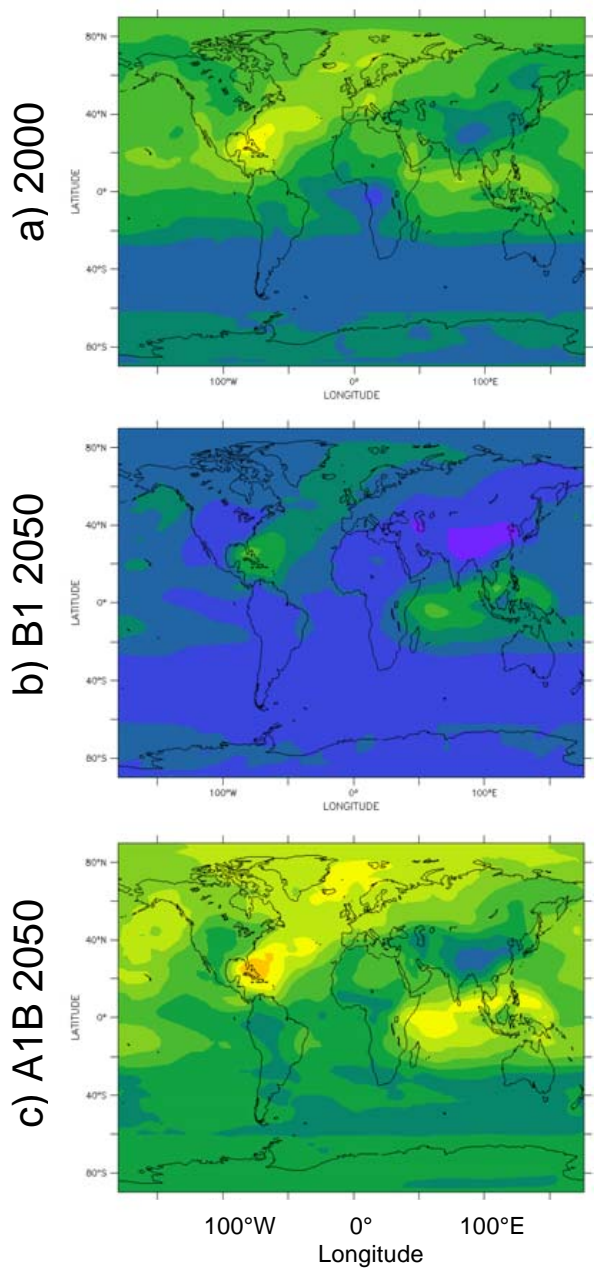

Zonal mean ozone

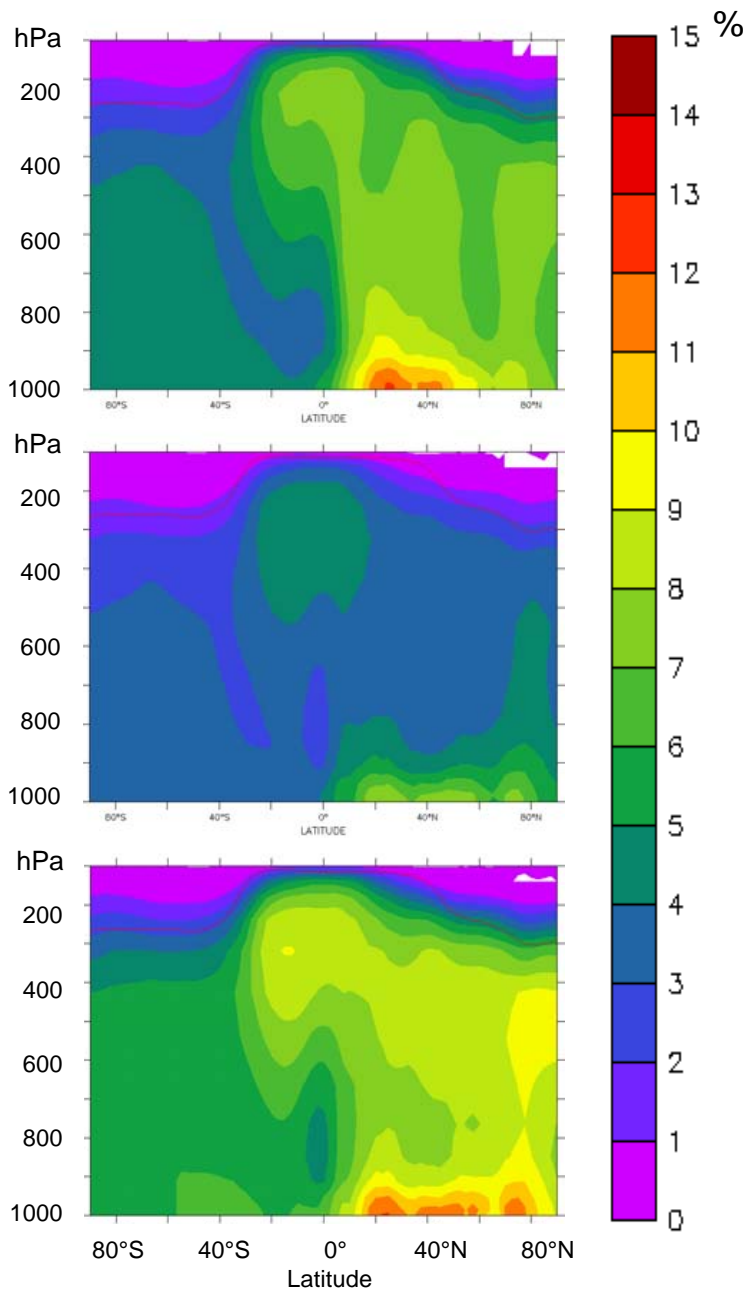

Fig. 5. Up-scaled perturbations (in \%) in the ozone tropospheric column (left) and in zonal mean ozone mixing ratio (right) due to all transport modes, obtained for July for 2000 (A experiment) and 2050 (B1 and A1B scenario, i.e., B and C experiments) emissions.

\subsubsection{B1 ACARE mitigation}

In order to assess the efficiency of possible aircraft emission reduction strategy, the B1 ACARE scenario was simulated for 2050. It corresponds to B1 emission scenario, but with a reduction of the aircraft emissions due to the implementation of ACARE targets (Table 3). It is characterized by low $\mathrm{NO}_{\mathrm{x}}$ global aircraft emissions (lower than for 2000), and can be seen as a more restricting but technically feasible scenario. The induced ozone perturbation for this scenario is illustrated and compared to 2000 and B1 2050 perturbations in Fig. 6. A $5 \%$ perturbation of aircraft emissions leads to a perturbation of less than $0.10 \%$ of the zonal mean ozone background of the upper troposphere of Northern Hemisphere, instead of up to $0.12 \%$ and $0.14 \%$ for 2000 and B1 2050 emissions, respectively (Fig. 6a). The ozone column perturbations show a decrease of $25 \%$ to $36 \%$ of the impact of aviation com- pared to B1 2050 (not shown). Whereas for B1 scenario, the aircraft impact increases over most of the globe from 2000 to 2050, the B1 ACARE scenario leads to an increase in the Southern Hemisphere (by up $+30 \%$ ), but a decrease in the Northern Hemisphere, by down to $-30 \%$ (Fig. 6b). Nevertheless, aviation would still be the major transport contributor to the ozone perturbation in the Northern Hemisphere in 2050 , by contributing by up to $70 \%$ to the total transport perturbation on the $\mathrm{O}_{3}$ column (not shown).

Figure 7a shows the sensitivity of the global ozone burden to each transport mode, for 2000, 2025 and 2050 emissions. The predominant perturbation mode shifts from road to aircraft (A1 scenario) or shipping (B1 scenario) from 2000 to 2050. This shift is due to changes in the respective emission amounts, whereas the ozone production efficiency $\left(\mathrm{O}_{3}\right.$ molecule per $\mathrm{NO}_{\mathrm{x}}$ molecule emitted) of each transport sector is not highly modified (Fig. 7b). In agreement with previous 


\section{a. Up-scaled ozone background perturbation (\%) due to aircraft emissions (July)}

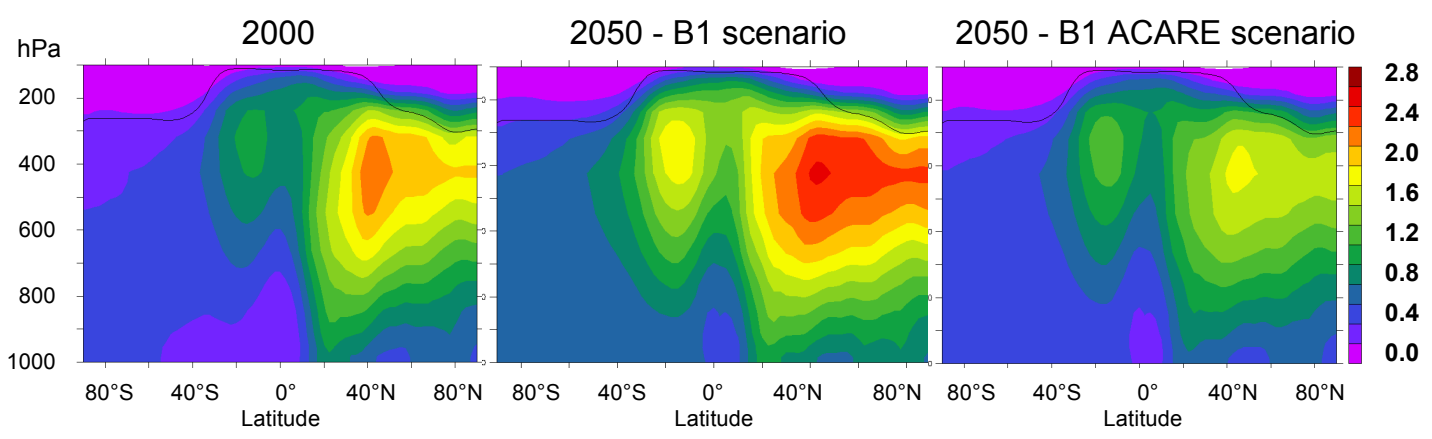

b. 2000 to 2050 change (\%) in the ozone perturbation due to aircraft emissions (July)
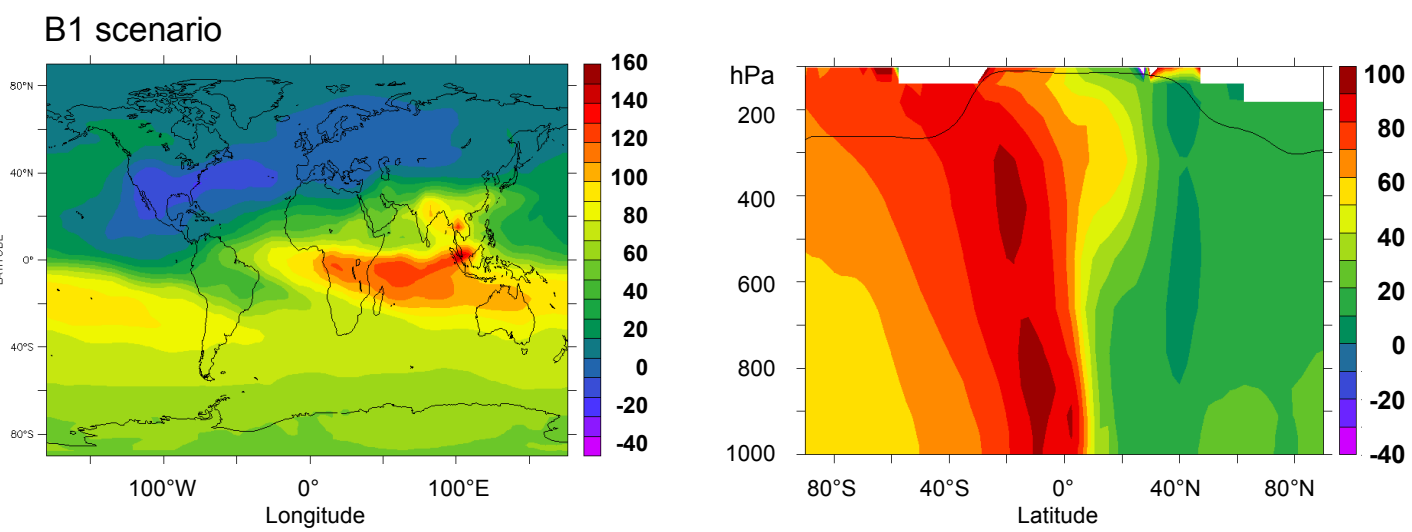

B1 ACARE scenario
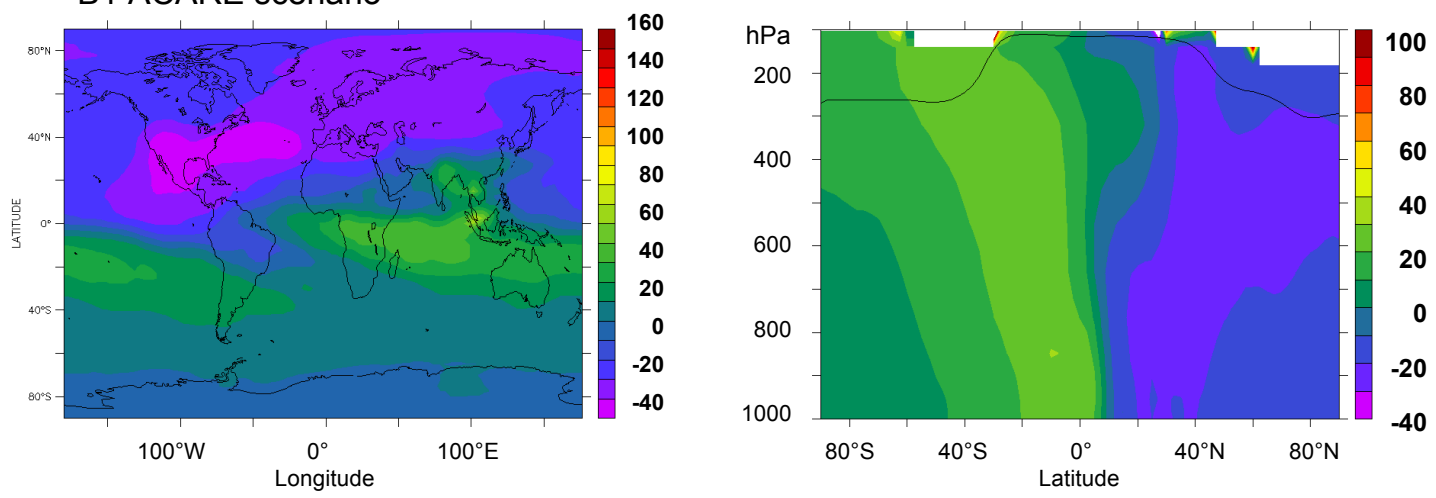

Fig. 6. (a) Perturbations in zonal mean ozone mixing ratio (in \%) due to aircraft emissions, for July from 2000 (left), 2050 B1 (middle) and 2050 B1 ACARE (right) emissions; (b) 2000-2050 changes (\%) in the $\mathrm{O}_{3}$ tropospheric column and zonal mean ozone perturbations by aircraft emissions for B1 scenario, and (c) B1 ACARE scenario.

studies (e.g., Hauglustaine et al., 2005; Gauss et al., 2006; Dahlmann et al., 2009; Hoor et al., 2009), aircraft $\mathrm{NO}_{\mathrm{x}}$ emissions show an ozone production efficiency about three times higher than road traffic and shipping, because they are emitted directly into the UTLS, where they lead to larger and more persistent perturbations compared to the Earth's surface. The shipping emissions, which largely occur in low polluted environments, have the highest net chemical production per $\mathrm{NO}_{\mathrm{x}}$ molecule (Fig. 7c).

\subsection{Influence of climate change}

In this part, we present the impact of transport emissions, in the context of climate changes for the A1B 2050 emission scenario. The effect of climate change on the future meteorological and chemical states of the troposphere is first presented. It is compared to available published results, which mainly concerned scenario A2 and year 2100. The innovative investigation of the changes in the transport-induced ozone perturbation due to climate change is then presented. 


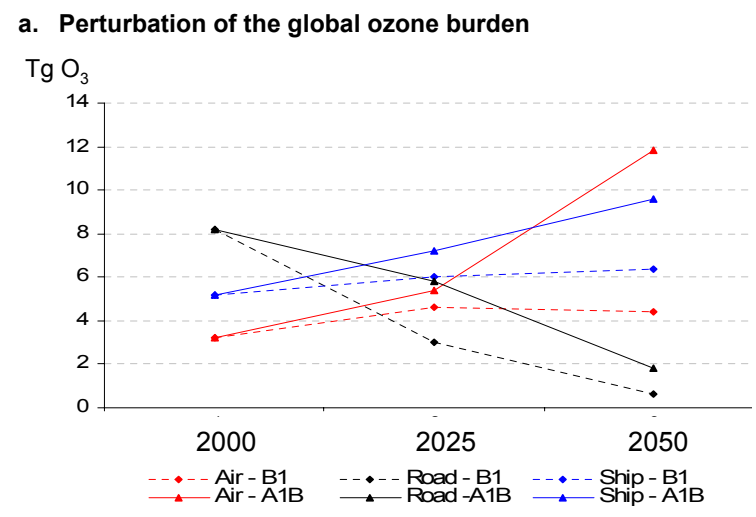

c. Perturbation of the global ozone chemical net production $\mathrm{Tg} \mathrm{O}_{3} \cdot \mathrm{yr}^{-1}$

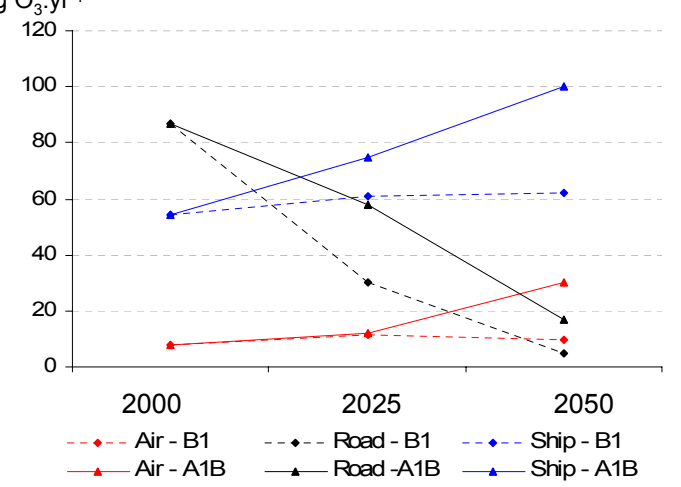

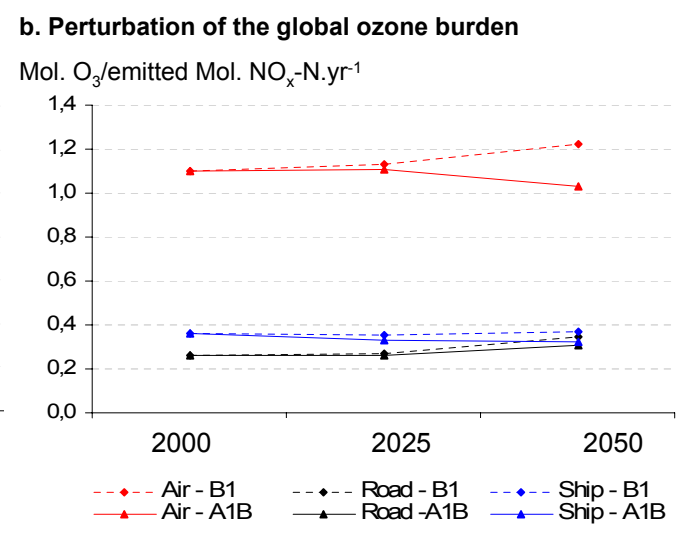

d. Perturbation of the global ozone chemical net production

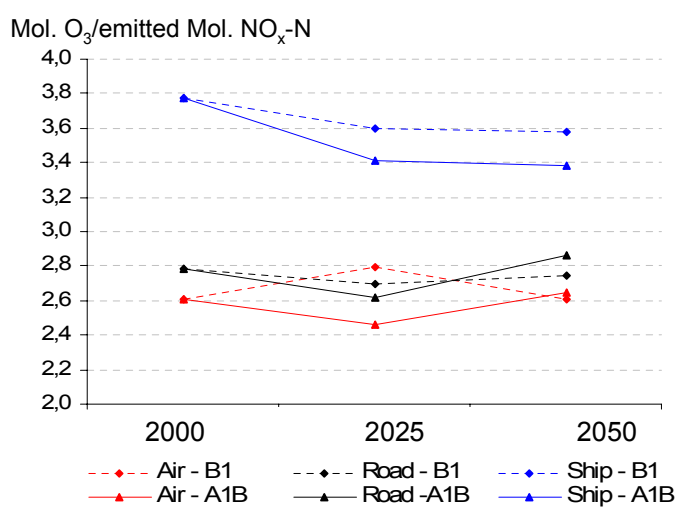

Fig. 7. Perturbation of the global ozone burden (a, b) and the global ozone chemical net production (c, d) due to 2000,2025 and 2050 emissions from aircraft, road traffic and shipping. Both the absolute (left) and the relative $\left(\mathrm{mol} . \mathrm{O}_{3}\right.$ per mol. of emitted $\mathrm{NO}_{\mathrm{x}}$; right) perturbations are presented.

\subsubsection{Change in global climate and tropospheric chemical composition}

The 2000-2050 climate change and its impacts on the background chemical composition of the troposphere are based on the differences between $\mathrm{E}$ and $\mathrm{F}$ simulations (Table 2).

The change in the global mean annual surface temperature $\left(+1.3{ }^{\circ} \mathrm{C}\right)$ as simulated by the $\mathrm{LMD}_{z}$-INCA model between the two time-slice periods is consistent with the last IPCC results (Meehl et al., 2007), which reported a 2000-2050 surface warming of $+1.4{ }^{\circ} \mathrm{C}$ for A1B emission scenario, from an ensemble of 21 models. Surface temperature changes less than $4{ }^{\circ} \mathrm{C}$ are predicted in annual mean over most of the globe. A similar change is also generally predicted for January and July (not shown), but reaching locally up to $9^{\circ} \mathrm{C}$ (e.g., over the US and Eastern Russia). The zonal mean temperature increases by up to $2.5^{\circ} \mathrm{C}$ throughout the troposphere in July. Lower changes are obtained in January South to $40^{\circ} \mathrm{N}$, but higher ones more North (Fig. 8a). An associated increase in water vapor is obtained in most of the troposphere, reaching up to $+60 \%$ in zonal mean in the UTLS region (Fig. 8b). These changes in temperature and water vapor are consistent with previous studies. For instance, Brasseur et al. (2006) predicted similar, but stronger changes (up to $150 \%$ for the water vapor) by July 2100 for the more pessimistic A2 scenario, using ECHAM5/OM-1 model. The 2000-2050 changes in precipitation rate (not shown) simulated in our study also show similar general trends (decrease in tropical Atlantic and increase in tropical Pacific) compared to the 2000-2100 precipitation change simulated by Brasseur et al. (2006) for A2 scenario. As a result of enhanced water vapour, a decrease in future global ozone burden is generally predicted, since more water vapor leads to more ozone loss through $\mathrm{O}^{1}(\mathrm{D})$ reaction with $\mathrm{H}_{2} \mathrm{O}$ (Stevenson et al., 2006). However, both positive and negative ozone changes are reported according to the altitude, the season, the model, the reference year or the scenario (e.g., Hauglustaine et al., 2005; Murazaki and Hess, 2006; Wu et al., 2008). Figure 9a shows the calculated 2000-2050 changes in the ozone, $\mathrm{NO}_{\mathrm{x}}$ and $\mathrm{CO}$ zonal means for scenario A1B, in January and July. We obtain similar spatial patterns, but logically lower magnitude of changes compared to the 2000-2100 changes illustrated in Brasseur et al. (2006) and Hauglustaine et al. (2005), for the more pessimist A2 scenario. A decrease of the ozone mixing ratio reaching up $10 \%$ is predicted in both hemispheres. Between $900 \mathrm{hPa}$ to $400 \mathrm{hPa}$, this net decrease is associated 


\section{a. Change in zonal mean temperature $\left({ }^{\circ} \mathrm{C}\right)$}

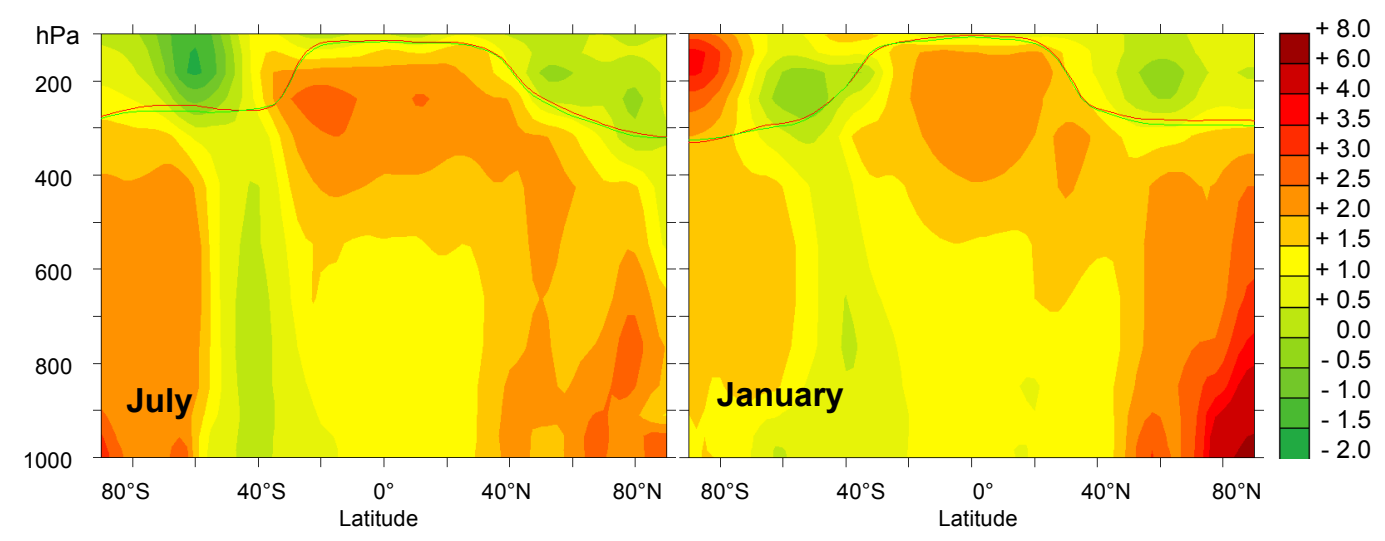

\section{b. Change in water vapour $(\%)$}

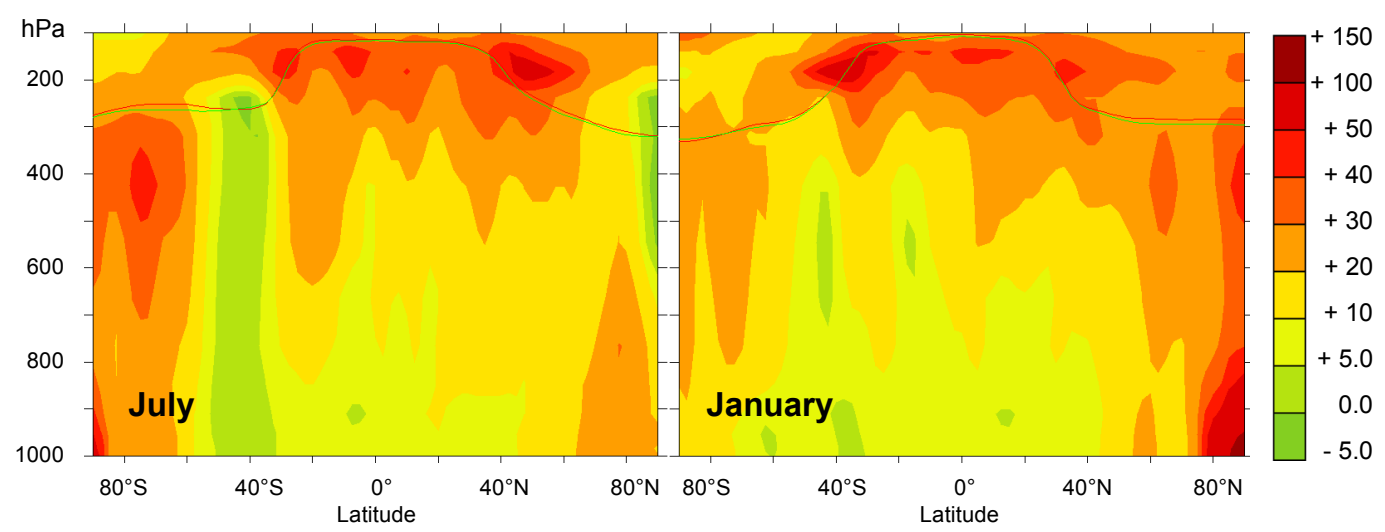

Fig. 8. Future (2050) change in zonal mean temperature (degrees) and water vapour (\%), for July (left) and January (right) conditions (A1B emission scenario).

with an increase in the chemical loss of ozone twice higher than the increase in the chemical production (not shown). In addition to these processes, the decrease of ozone also predicted in the lower troposphere (below $800 \mathrm{mb}$ ) around $20^{\circ} \mathrm{N}$ and $20^{\circ} \mathrm{S}$ in July and January respectively, is due to a shorter lifetime of ozone and peroxyacetylnitrate (PAN) at warmer temperatures (Wang et al., 1998; Hauglustaine et al., 2005; Brasseur et al., 2006; Wu et al., 2008). This process would allow explaining the associated increase in $\mathrm{NO}_{\mathrm{x}}$ concentrations (Fig. 9b) and the strong positive change in ozone chemical net production at these altitudes (not shown). According to the latter previous studies, the larger ozone decrease (up to $6 \%-10 \%)$ predicted in the upper troposphere $(\sim 300 \mathrm{hPa})$ could also reflect the elevation of the tropopause height due to climate change (see also Collins et al., 2003).

In a warmer climate, the hydrological cycle is more active and the convection enhanced. Such an increase in convection and the related lightning $\mathrm{NO}_{\mathrm{x}}$ production were shown to have a strong impact on $\mathrm{NO}_{\mathrm{x}}$ background concentrations, and thus on the magnitude of the anthropogenic perturbations on upper tropospheric ozone. On one hand, it was shown to lead to a higher production of lightning $\mathrm{NO}_{\mathrm{x}}$, and thus to an increase in $\mathrm{NO}_{\mathrm{x}}$ and ozone concentrations, especially in the tropics (Hauglustaine et al., 2005; Zhao et al., 2009). On the other hand, the stronger vertical mixing due to convection reduces the $\mathrm{NO}_{\mathrm{x}}$ background concentrations in the upper troposphere of extra-tropical regions, and consequently to increase the ozone production efficiency of aircraft $\mathrm{NO}_{\mathrm{x}}$ emissions. Results from our simulations show an increase by up to $25 \%$ in $\mathrm{NO}_{\mathrm{x}}$ background concentrations in the upper troposphere over the inter-tropical region (Fig. 9b). This climate-induced increase is due to the $\mathrm{NO}_{\mathrm{x}}$ production by lightning, which is shown to increase by $7.3 \%$ at global scale because of enhanced convection, from 4.67 to $4.84 \mathrm{Tg} \mathrm{NO}_{\mathrm{x}}{ }^{-}$ $\mathrm{N}$. As a consequence, the zonal mean ozone concentration increases by up to $4 \%$ in the UTLS in this region. Inversely, in the extra-tropical latitudes, a decrease in $\mathrm{NO}_{\mathrm{x}}$ background concentrations by more than $25 \%$ is predicted in the mid and upper tropospheres in July, and throughout the troposphere in January. 
a. Change in zonal mean $\mathrm{O}_{3}(\%)$
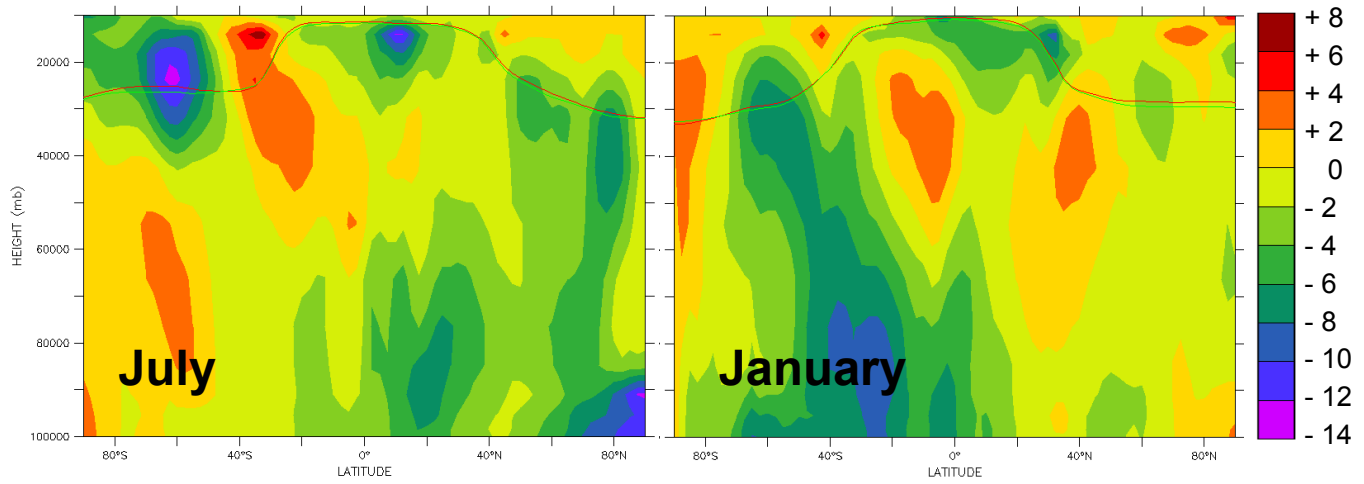

\section{b. Change in zonal mean $\mathrm{NO}_{x}(\%)$}
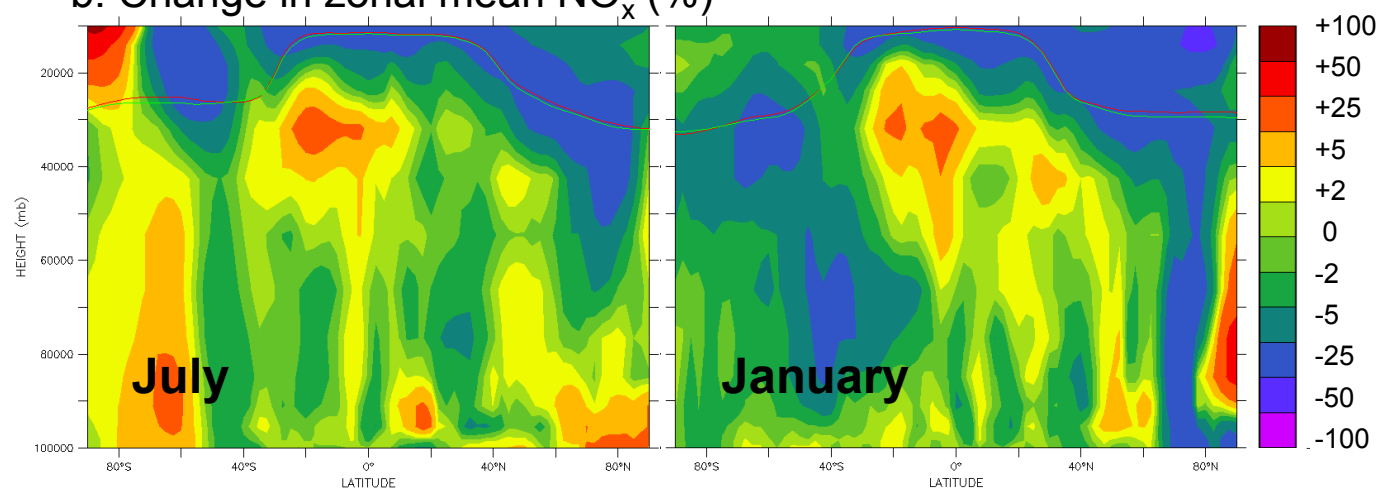

Fig. 9. Future change in $\mathrm{O}_{3}(\%)$ and $\mathrm{NO}_{\mathrm{x}}(\%)$ zonal mean mixing ratio, for July (left) and January (right) conditions (A1B emission scenario).

\subsubsection{Change in the impact of transport on tropospheric chemistry}

In this section, we assess the effect of climate change on the impact of future transport emissions on tropospheric ozone, from present (Case E) and future (Case F) base and perturbation runs (Table 4). As done in the previous section, the transport perturbations were assessed by a $5 \%$ perturbation of emissions, subsequently up-scaled to $100 \%$. While this approach was shown to under-estimate by $8 \%$ the global transport-induced ozone perturbation, it does not significantly affect the evaluation of its changes due to climate change, since it was applied to both present and future climates. The simulated impact of 2000 (Fig. 10a) and A1B 2050 (Fig. 10b) transport emissions on the ozone column in a present climate are consistent with the results previously obtained from 2003 meteorological runs (Fig. 1b). Similar spatial patterns but slightly lower perturbations are obtained for these climatic runs. The general patterns of the impact of A1B 2050 transport emissions on the ozone column are very similar in the future (Fig. 10c) and present (Fig. 10b) climate. In both cases, an increase in the ozone column is predicted, with (up-scaled) maxima of +5.0 DU (January) and +5.5 DU (July) in the Northern Hemisphere.
In July, the most impacted area ( $>4.0 \mathrm{DU})$ mainly extends from the Eastern US to Eastern Europe, and also includes a large part of the Mediterranean region. In January, Asia and the North Pacific Ocean also experience an increase by up to +5.0 DU (present climate) and +4.5 DU (future climate). The perturbation of the ozone zonal mean mixing ratio (not shown) reaches +9 (and +9 ) ppbv in the upper troposphere of the Northern Hemisphere in July, and +7.5 (and +8.0) ppbv in January, for the present (and future) climates. These results are consistent with the nudged simulations results, which showed that this high impact of 2050 transport emissions in the upper troposphere in the Northern Hemisphere was due for a large part to the aircraft emissions and their high ozone production efficiency (Figs. 4 and 5).

While very similar global patterns for the impact of transport emissions on ozone are predicted with and without the climate change, significant positive or negative climateinduced changes are simulated according to the region, altitude and season. An increase of up to $+0.6 \mathrm{DU}$ is simulated in January in both northern (North Pacific) and southern (West coast of South-America) hemispheres (Fig. 1a). In July, the climate change enhances the effect of transport emissions in the already most impacted zone, by up to $0.4 \mathrm{DU}$ (i.e, by $+10 \%$ ) in the Gulf of Mexico (Fig. 11b). In Western Europe, 
Table 4. Impact of changes in emissions and in climate, on the global tropospheric chemistry. "O $\mathrm{O}_{3}$ prod.", "O $\mathrm{O}_{3}$ loss" and " $\mathrm{O}_{3}$ net" refer to the $\mathrm{O}_{3}$ chemical production, $\mathrm{O}_{3}$ chemical loss and $\mathrm{O}_{3}$ chemical net production, respectively. The $r$ subscript letter refers to $5 \%$ reduction of transport emissions. See Table 2 for the definition of the D, E and F experiments.

\begin{tabular}{lrrrrrrrr}
\hline $\begin{array}{l}\text { Changes in the global tropospheric } \\
\text { chemistry due to: }\end{array}$ & $\begin{array}{r}\mathrm{NO}_{\mathrm{x}} \\
\text { light. }\end{array}$ & $\mathrm{OH}$ & $\begin{array}{r}\mathrm{CH}_{4} \\
\text { lifetime }\end{array}$ & $\begin{array}{r}\mathrm{O}_{3} \\
\text { burden }\end{array}$ & $\begin{array}{r}\mathrm{O}_{3} \\
\text { prod. }\end{array}$ & $\begin{array}{r}\mathrm{O}_{3} \\
\text { loss }\end{array}$ & $\begin{array}{r}\mathrm{O}_{3} \\
\text { net }\end{array}$ & Case \\
\hline 2000 to 2050 emission change & $0,0 \%$ & $-1.3 \%$ & $+3.3 \%$ & $+10.1 \%$ & $+12.4 \%$ & $+13.8 \%$ & $+8.0 \%$ & (E-D)/D \\
2000 to 2050 climate change & $7,3 \%$ & $+2.3 \%$ & $-4.7 \%$ & $-1.2 \%$ & $+2.4 \%$ & $+3.9 \%$ & $-2.7 \%$ & (F-E)/E \\
Emissions and climate changes & $7.3 \%$ & $+1.0 \%$ & $-1.6 \%$ & $+8.8 \%$ & $+15.0 \%$ & $+18.3 \%$ & $+5.1 \%$ & $(\mathrm{~F}-\mathrm{D}) / \mathrm{D}$ \\
2000 transport emissions in a present climate & $0,0 \%$ & $+5.4 \%$ & $-6.5 \%$ & $+5.4 \%$ & $+8.8 \%$ & $+7.8 \%$ & $+12.7 \%$ & {$[(\mathrm{D}-\mathrm{Dr}) \cdot 20] / \mathrm{D}$} \\
2050 transport emissions in a present climate & $0.0 \%$ & $+9.0 \%$ & $-9.7 \%$ & $+6.6 \%$ & $+9.6 \%$ & $+8.7 \%$ & $+12.2 \%$ & {$[(\mathrm{E}-\mathrm{Er}) \cdot 20] / \mathrm{E}$} \\
2050 transport emissions in a future climate & $0,0 \%$ & $+9.0 \%$ & $-9.7 \%$ & $+6.6 \%$ & $+9.6 \%$ & $+8.7 \%$ & $+12.5 \%$ & [(F-Fr) $\cdot 20] / \mathrm{F}$ \\
\hline
\end{tabular}

Table 5. Impact of changes in emissions and in climate on the perturbation of the global tropospheric chemistry by the transport emissions. " $\mathrm{O}_{3}$ prod.", " $\mathrm{O}_{3}$ loss" and " $\mathrm{O}_{3}$ net" refer to the $\mathrm{O}_{3}$ chemical production, $\mathrm{O}_{3}$ chemical loss and $\mathrm{O}_{3}$ chemical net production, respectively. The $r$ subscript letter refers to $5 \%$ reduction of transport emissions. See Table 2 for the definition of the D, E and F experiments.

\begin{tabular}{lrrrrrrl}
\hline $\begin{array}{l}\text { Change in the transport-induced } \\
\text { perturbations due to: }\end{array}$ & $\mathrm{OH}$ & $\begin{array}{r}\mathrm{CH}_{4} \\
\text { lifetime }\end{array}$ & $\begin{array}{r}\mathrm{O}_{3} \\
\text { burden }\end{array}$ & $\begin{array}{r}\mathrm{O}_{3} \\
\text { prod. }\end{array}$ & $\begin{array}{r}\mathrm{O}_{3} \\
\text { loss }\end{array}$ & $\begin{array}{r}\mathrm{O}_{3} \\
\text { net }\end{array}$ & Case \\
\hline 2000 to 2050 emission change & $+65 \%$ & $+53 \%$ & $+37 \%$ & $+22 \%$ & $31 \%$ & $+4 \%$ & $[(\mathrm{E}-\mathrm{Er})]-(\mathrm{D}-\mathrm{Dr})] /(\mathrm{D}-\mathrm{Dr})$ \\
2000 to 2050 climate change & $+1.9 \%$ & $-4.8 \%$ & $-1.6 \%$ & $+2.7 \%$ & $+3.9 \%$ & $+0.1 \%$ & {$[(\mathrm{~F}-\mathrm{Fr})-(\mathrm{E}-\mathrm{Er})] /(\mathrm{E}-\mathrm{Er})$} \\
2000 to 2050 emissions and climate changes & $+68 \%$ & $+46 \%$ & $+35 \%$ & $+25 \%$ & $+36 \%$ & $+4 \%$ & {$[(\mathrm{~F}-\mathrm{Fr})-(\mathrm{D}-\mathrm{Dr})] /(\mathrm{D}-\mathrm{Dr})$} \\
\hline
\end{tabular}

an increase reaching up 0.3 DU (July) and 0.4 DU (January) is obtained, corresponding to $+6 \%$ and $+12 \%$, respectively. Decreases of the same order of magnitude are also predicted in SE Asia in January ( -0.6 DU corresponding to $-20 \%)$, but also over Africa and in the North Pacific in July $(-0.5$ DU, i.e., $-16 \%)$. The changes in the zonal mean mixing ratio (Fig. 11c) show an increase throughout the troposphere north to $20^{\circ} \mathrm{N}$, which reaches up to $0.5 \mathrm{ppbv}$ at the tropopause level, i.e. $8 \%$ of the impact of transport (Fig. 11c). This increase clearly results from the decrease in $\mathrm{NO}_{\mathrm{x}}$ background concentrations predicted throughout the troposphere in January, that leads to an enhanced ozone production efficiency of $\mathrm{NO}_{\mathrm{x}}$ emissions, and notably of aircraft emissions. In July, a similar increase is obtained in the upper troposphere for the same reasons, whereas the impact of transport emissions on ozone decreases by $0.5 \mathrm{ppbv}(-8 \%)$ in the low troposphere (around $800 \mathrm{hPa}$ ) of Northern Hemisphere (Fig. 11d). As for the ozone background levels (Fig. 9a), this decrease is related to the increase in the water vapor content and the associated decrease in the net ozone chemical production. In the Southern Hemisphere, except for the southern polar region (July), and around $20^{\circ} \mathrm{S}$ latitude (January), a decrease of the impact of the transport emission is generally predicted, which reaches $-0.6 \mathrm{ppbv}$ in the upper troposphere of the inter-tropical region. Figure 12 shows the seasonality of the zonal mean ozone column perturbation as simulated by LMDz-INCA for the present and future climates. In both cases, the minimum and maximum transport-induced perturbations are calculated for summer and winter, respectively. A more pronounced perturbation change is calculated for winter than for summer. The main reason for this is that the effect of aircraft emissions on the ozone perturbation, which is approximately half as large during January compared to July, becomes highly dominant in future according to the A1B future scenario.

The global effects of climate and emissions changes on the ozone background and on the transport-induced ozone are summarized in Table 4 and Table 5, respectively. Changes in the $\mathrm{OH}$ concentration and $\mathrm{CH}_{4}$ lifetime are also reported. The results show that the changes in all anthropogenic emissions increase the global tropospheric $\mathrm{O}_{3}$ burden by about $10 \%$, whereas the climate change leads to a decrease of $1.2 \%$. This decrease is due to an increased ozone chemical loss $(+3.9 \%)$ which dominates the increase in the ozone chemical production $(+2.4 \%)$, as discussed in section 4.31 . As a consequence of both emissions and climate changes, the ozone burden increases by $8.8 \%$ in annual mean (Table 4 ). The atmospheric chemical perturbations from transport emissions are affected by climate change in a similar magnitude as the background chemistry (Table 5). The transport-induced ozone production and destruction rates are increased by $2.7 \%$ and $3.9 \%$, respectively. As result, the perturbation of the ozone burden due to transport emissions decreases by $1.6 \%$ because of climate change. In comparison, the changes in 
a) Impact of 2000 transport emissions in a 2000 climate
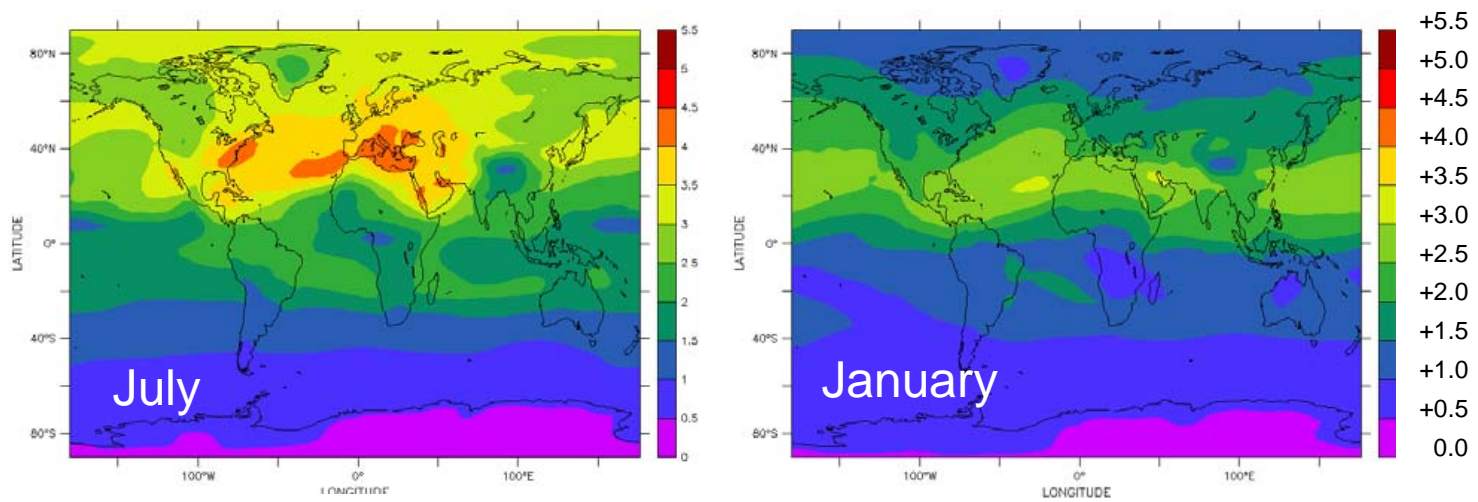

b) Impact of 2050 transport emissions in a 2000 climate
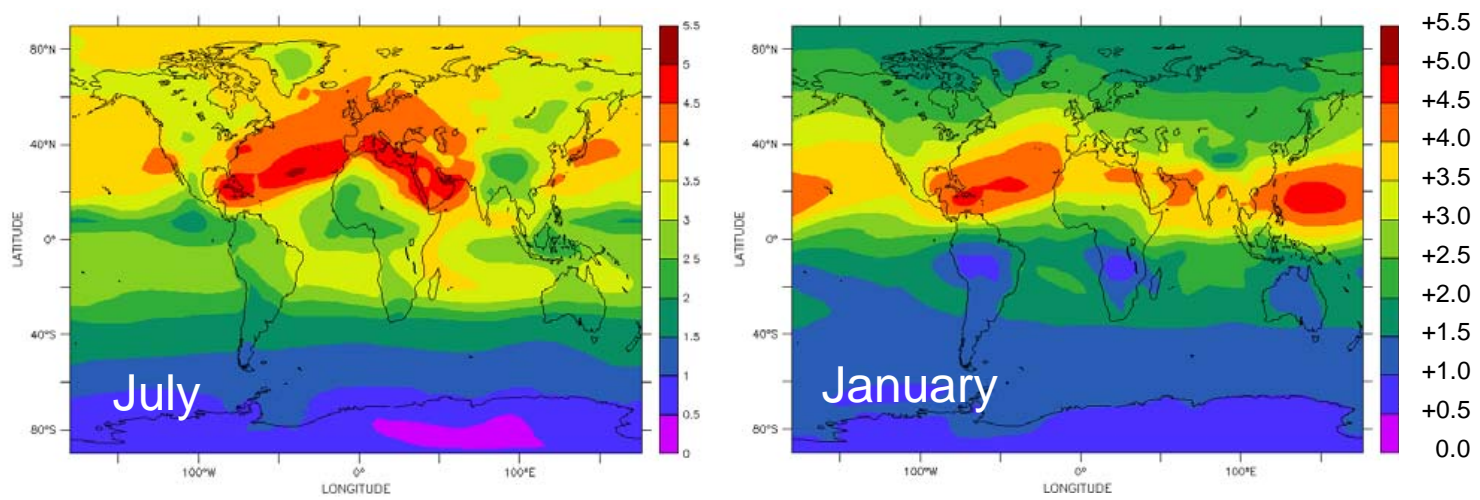

c) Impact of 2050 transport emissions in a 2050 climate
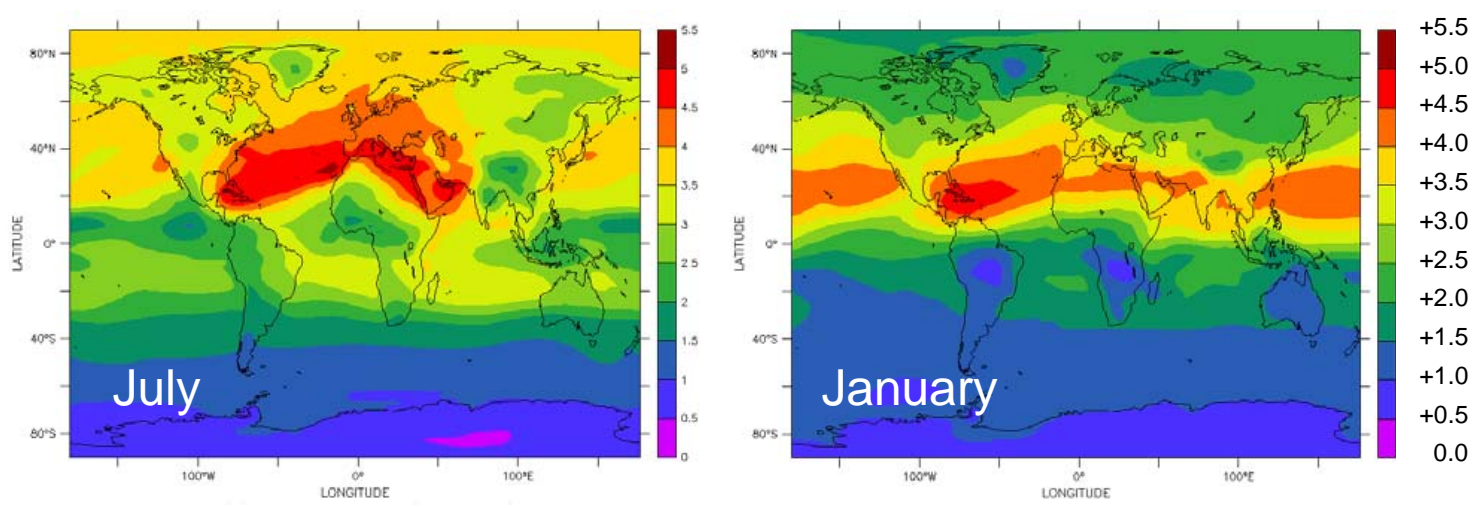

Fig. 10. Up-scaled tropospheric ozone column perturbation ( $\Delta$ DU) due to (a) 2000 transport emissions in a present climate and (b) 2050 transport emissions in a present climate, (c) 2050 transport emissions in a future climate, as simulated for July (left) and January (right) conditions (A1B emission scenario).

anthropogenic emissions (including transport) lead to an increase of $+37 \%$ of the transport-induced ozone. In other words, the change in the global ozone burden in 2050 due to changes in anthropogenic emissions is lowered by $12 \%$ and $4 \%$ because of climate change effects, for the background and the transport-induced ozone, respectively.

\section{Conclusions}

The emissions by the transport sector have a major influence on both air quality and climate. Significant changes in emissions and climate conditions are expected to occur in the future, which will modify their impact on the atmospheric chemical composition. In this study, we investigated how the 2000 to 2050 changes in emissions and climate will modify the impact of transport (road, ship and aircraft) emissions on 
a. Change in the ozone column

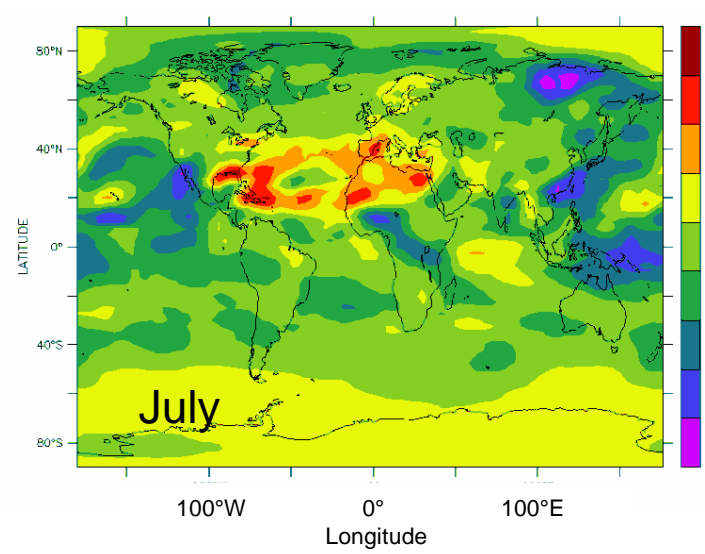

\section{b. Change in the zonal mean ozone}

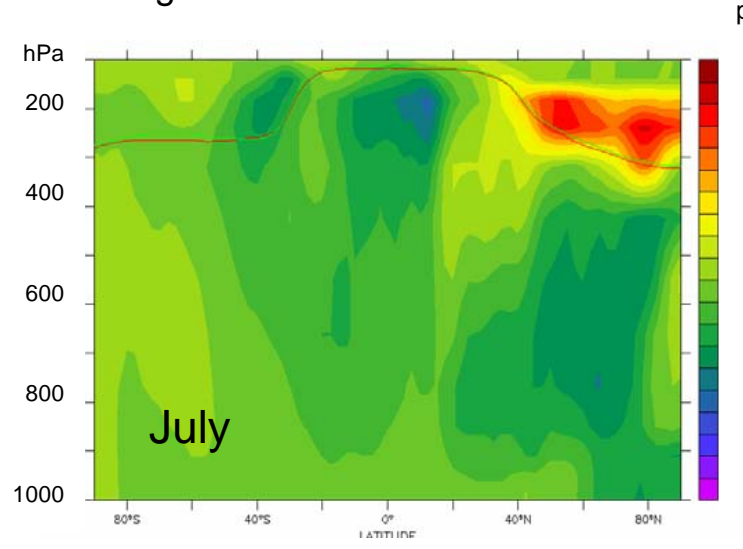

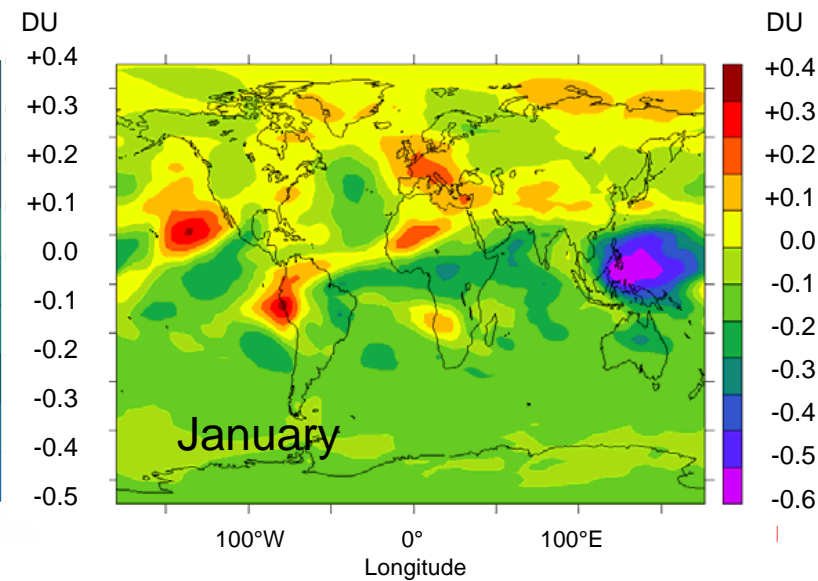

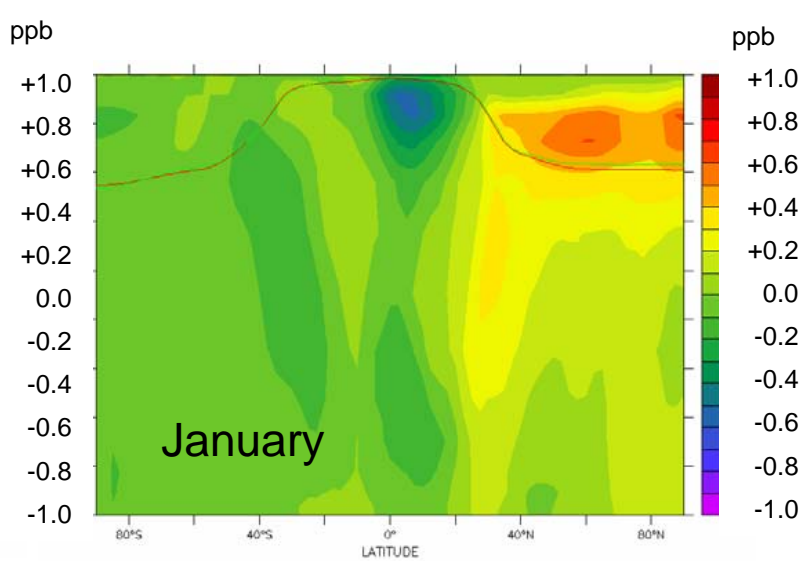

Fig. 11. Effect of future (2050) climate change on the impact of transport emissions on (a) the tropospheric ozone column ( $\Delta$ DU) and (b) on zonal mean ozone mixing ratio $\left(\Delta \mathrm{ppb}_{v}\right)$ for July (left) and January (right) conditions (A1B scenario).

tropospheric ozone. The LMDz-INCA model and up-to-date global inventories and scenarios of anthropogenic emissions provided by the EU QUANTIFY project were used. A small (5\%) scale perturbation approach was applied to assess separately the ozone sensitivity to each transport mode. Its upscaling to $100 \%$ also provides an approximative (but locally under-estimated) assessment of the total impact of the transport emissions on the global tropospheric chemistry.

Firstly, we assessed the combined and relative effects of present (2000) and future (2050) emissions by the three transport modes (road traffic, shipping and aircraft) in a present-day climate. While changes in all anthropogenic emissions are considered by 2050 , only induced changes in the role of the transport sector on the tropospheric chemistry are discussed. The present emissions mainly affect the ozone levels in the Northern Hemisphere, with a maximum increase extending from the South-Eastern US to Central Europe. The total perturbation (+5 DU) accounts for $4 \%$ to $10 \%$ of the ozone column. It is dominated in the lower troposphere by road traffic over land, and by shipping over marine regions. In the middle/upper troposphere, road traffic dominates North of $40^{\circ} \mathrm{S}$, and shipping more South.

As a consequence of a strong reduction in road traffic and a moderate (B1 scenario) to high (A1B scenario) increase in ship and aircraft emissions in 2050, a drastic decrease in the impact of road emissions is projected, whereas aviation becomes the major transport perturbation on the tropospheric ozone, even in the case of a very optimistic mitigation scenario (B1 ACARE). Despite similar global $\mathrm{NO}_{\mathrm{x}}$ emissions in 2000 and 2050, the A1B scenario leads to an increase of the impact of transport on ozone by up to $+30 \%$ and $+50 \%$ in the Northern and Southern Hemispheres, respectively. The increase is the most pronounced in the UTLS region in the Northern Hemisphere, where transport emissions account for about $8-9 \%$ of the ozone background, instead of $4-5 \%$ and 6-7\% for B1 2050 and 2000 emissions, respectively. This is mainly due to the high increase in aircraft exhausts, and their high ozone production efficiency, due to longer $\mathrm{NO}_{\mathrm{x}}$, PAN and $\mathrm{HNO}_{3}$ lifetimes in the UTLS region. Thus, the future changes in the ozone perturbation due to the transport sector 
a. Zonal mean ozone column perturbation in a present climate (DU)

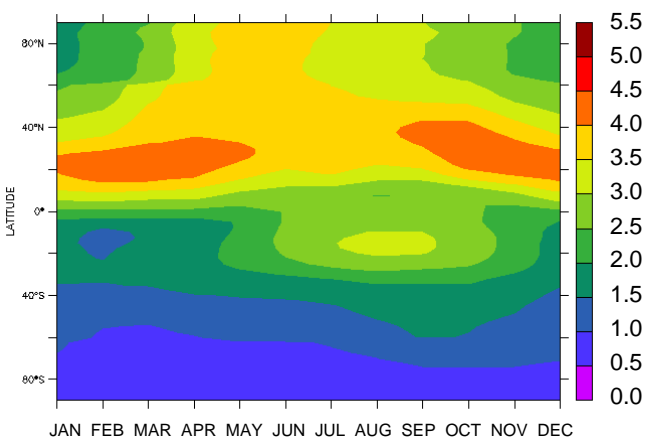

b. Zonal mean ozone column perturbation in a future climate (DU)

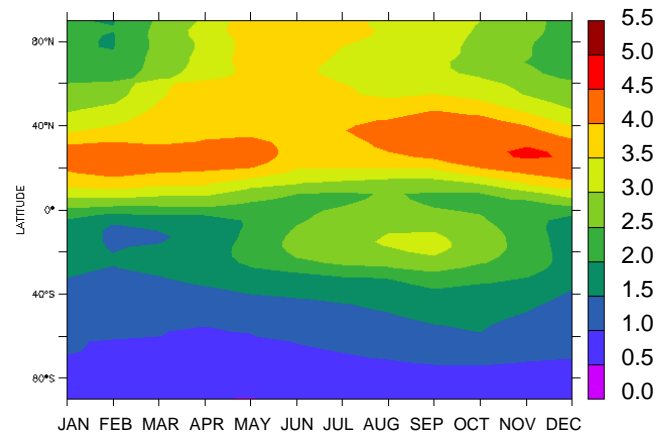

c. Change in the zonal mean ozone column perturbation (DU)

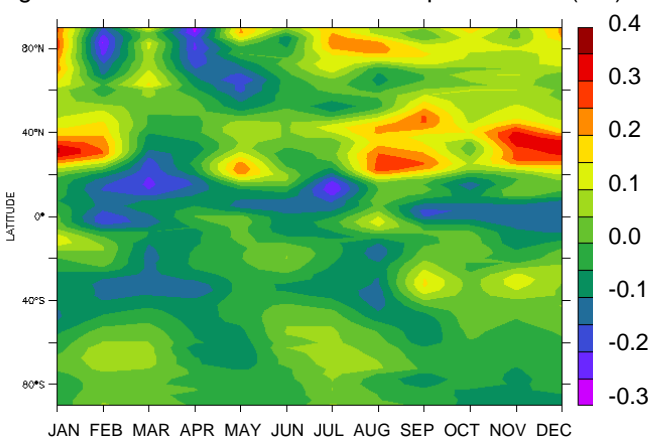

Fig. 12. Impact of transport emissions on the zonal mean tropospheric ozone column (a) in a present and (b) in a future (A1B scenario, 2050) climate, and (c) corresponding change ( $\Delta \mathrm{DU})$.

are dominated by the amount, but also the shift in the emission share between the three transport sources, whereas the ozone production efficiency by each transport mode is only slightly modified at the global scale.

The impact of 2000 to 2050 climate change on both the ozone background and on the combined (road, ship and aircraft) transport-induced ozone has also been simulated. The climate change for A1B emission scenario has been investigated, which corresponds to a surface global warming of $1.3^{\circ} \mathrm{C}$ in 2050 . The mean zonal temperature is increased by up to $2.5^{\circ} \mathrm{C}$ throughout the troposphere, reaching $+3.0^{\circ} \mathrm{C}$ in low and mid troposphere of Northern Hemisphere, and in the upper troposphere of the inter-tropical zone. An associated increase in the water vapor by up to $40 \%$ and $60 \%$ is obtained in zonal mean in the mid and upper troposphere. As a global result, a decrease by $1.2 \%$ of the $\mathrm{O}_{3}$ burden is predicted. However, positive and negative effects are highlighted according to the location, altitude and season, because of the combined effects of changes in temperature, background chemistry, atmospheric transport and mixing properties of the troposphere. Thus, the background ozone concentration is lowered in Southern Hemisphere, and enhanced in Northern Hemisphere, in January, whereas opposite trends are simulated for July. In both cases, ozone background increases in the upper-troposphere of the inter-tropical zone, due to an enhanced convection, and an associated increase in $\mathrm{NO}_{\mathrm{x}}$ lightning production.

The general patterns of the impact of the A1B 2050 transport emissions on the ozone column are not very different in a present and in a future climate. While the transport-induced global ozone burden is lowered by $1.6 \%$ in a future climate compared to the present climate, positive or negative changes are predicted according to the region, altitude and season. In July, the impact of transport emissions on the ozone column is enhanced by about $10 \%$, in the already most impacted zone, extending from the South-Eastern US to Central Europe. Increases of the same magnitude are also simulated in January, but in both northern and southern hemispheres. In Western Europe, the tropospheric ozone column perturbation by the transport emissions is enhanced by $+12 \%$ in January and $+6 \%$ in July, because of climate change. Decreases in the ozone column perturbation are also predicted in some regions during winter (e.g. in Asia) and summer (e.g. in Africa) seasons. In zonal mean, the impact of climate change on the transport-induced ozone is characterized by an increase by up to $+8 \%$ of the ozone perturbation in the upper troposphere, North to $20^{\circ} \mathrm{N}$. This increase is associated with lowered $\mathrm{NO}_{\mathrm{x}}$ background concentrations due to enhanced convection and dilution processes. While the impact of transport emissions is also enhanced in the low and middle troposphere of Northern Hemisphere in January, it decreases by up to $8 \%$ in the low troposphere (around $800 \mathrm{hPa}$ ) in July, because of a decrease in the net ozone chemical production due to enhanced water vapor. In the UTLS of the inter-tropical region, the impact of transport emissions is lowered with climate change in both seasons. This can be explained by a decrease in the ozone production efficiency due to higher $\mathrm{NO}_{\mathrm{x}}$ lightning production. In the Southern Hemisphere, except for the southern polar region (July), and around $20^{\circ} \mathrm{S}$ latitude (January), a decrease of the impact by the transport emission is generally predicted.

To summarize, we showed that the future changes in the impact of transport emissions on the tropospheric ozone will be highly dominated by the changes in the transport emissions, both in terms of total amount and shift between the three transport modes. According to our simulations, aviation will become the main transport source of ozone perturbation by 2050 , even in the case of very optimistic aircraft mitigation scenario. In the case of A1B scenario, the effects 
of 2000 to 2050 climate change reduce the global effect of emissions changes on the ozone burden and on the transportinduced ozone by $12 \%$ and $4 \%$, respectively. However, the ozone production efficiency of transport emissions can be locally significantly enhanced or reduced because of associated changes in the tropospheric background chemical composition, and/or in scavenging and dilution processes. This is particularly true for the ozone production in the UTLS, where it is of main importance to reduce the present-day uncertainties on the $\mathrm{NO}_{\mathrm{x}}$ lightning production in the models. These transport-related tropospheric perturbations have to be considered together with potential impacts of transport emissions on $\mathrm{CO}_{2}$, aerosols, and radiative forcing, which are not investigated here, but in other QUANTIFY related studies (e.g., Fuglestvedt et al., 2008; Berntsen and Fuglestvedt, 2008; Dahlmann et al., 2009; Balkanski et al., 2010; Myhre et al., 2011).

Acknowledgements. This work was funded by the European Union within the FP6 QUANTIFY project, under contract 003893. It was also partly supported by the 'Division des programmes de l'Aviation Civile (DPAC)'. Emission data sets were provided by DNV (shipping), DLR (road traffic), MMU (aircraft) and JRC (other anthropogenic emissions) QUANTIFY partners. We thank Jens Borken (IIASA) and the anonymous reviewers for their helpful comments on the manuscript.

Edited by: R. Harley

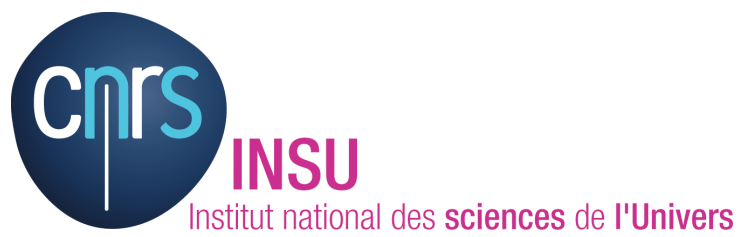

The publication of this article is financed by CNRS-INSU.

\section{References}

Andreae, M. and Merlet, P.: Emission of trace gases and aerosols from biomass burning, Global Biogeochem. Cy., 15, 955-966, 2001.

Balkanski, Y., Myhre, G., Gauss, M., Rädel, G., Highwood, E. J., and Shine, K. P.: Direct radiative effect of aerosols emitted by transport: from road, shipping and aviation, Atmos. Chem. Phys., 10, 4477-4489, doi:10.5194/acp-10-4477-2010, 2010.

Berntsen, T. and Fuglestvedt, J.: Global temperature responses to current emissions from the transport sectors, Proc. Natl. Acad. Sci., USA, 105, 19154-19159, 2008.

Brasseur, G., Muller, J., and Granier, C.: Atmospheric impact of $\mathrm{NO}_{\mathrm{x}}$ emissions by subsonic aircraft: a three-dimensional model study, J. Geophys. Res., 101, 1423-1428, 1996.

Brasseur, G., Cox, R., Hauglustaine, D. A., Isaksen, I. S. A., Lelieveld, J., Lister, D., Sausen, R., Schumann, U., Wahner, A., and Wiesen, P.: European scientific assessment of the atmospheric effect of aircraft emissions, Atmos. Environ., 32, 23292418, 1998a.
Brasseur, G., Hauglustaine, D. A., Walters, S., Rasch, P. J., Müller, J. F., Granier, C., and Tie, X. X.: MOZART, a global chemical transport model for ozone and related chemical tracers: 1 . Model description, J. Geophys. Res., 103, 28265-28289, 1998b.

Brasseur, G. P., Schultz, M., Granier, C., Saunois, M., Diehl, T., Botzet, M., Roeckner, E., and Walters, S.: Impact of climate change on the future chemical composition of the global troposphere, J. Climate, 19, 3932-3951, doi:10.1175/JCLI3832.1, 2006.

Borken-Kleefeld, J., Steller, H., Ceuster, G. D., Vanhove, F., Eide, M., Endresen, O., Behrens, H., Lee, D., Owen, B., Meretei, T., Rypdal, K., Skeie, R. B., van Aardenne, J., Erhardt, G., and Sausen, R.: QUANTIFY transport emission scenarios up to 2100, Environ. Sci. Technol., in preparation, 2010.

Cariolle, D., Caro, D., Paoli, R., Hauglustaine, D. A., Cuénot, B., Cozic, A., and Paugam, R.: Parameterization of plume chemistry into large-scale atmospheric models: Application to aircraft $\mathrm{NO}_{\mathrm{x}}$ emissions, J. Geophys. Res., 114, D19302, doi:10.1029/2009JD011873, 2009.

Collins, W. J., Derwent, R. G., Garnier, B., Johnson, C. E., Sanderson, M. G., and Stevenson, D. S.: Effect of stratospheretroposphere exchange on the future tropospheric ozone trend, J. Geophys. Res., 108(D12), 8528, doi:10.1029/2002JD002617, 2003.

Corbett, J. and Koehler, H.: Updated emissions from ocean shipping, J. Geophys. Res., 108, 4650, doi:10.1029/2003JD003751, 2003.

Crutzen, P., Lawrence, M., and Pöschl, U.: On the background photochemistry of tropospheric ozone, Tellus, 51A-B, 123-146, 1999.

Dahlmann, K., Grewe, V., Ponater, M., and Matthes, S.: Attribution of ozone radiative forcing trend to individual $\mathrm{NO}_{\mathrm{x}}$ sources, Atmos. Chem. Phys. Discuss., 9, 16131-16162, doi:10.5194/acpd9-16131-2009, 2009.

Dalsøren, S. B., Eide, M. S., Endresen, Ø., Mjelde, A., Gravir, G., and Isaksen, I. S. A.: Update on emissions and environmental impacts from the international fleet of ships: the contribution from major ship types and ports, Atmos. Chem. Phys., 9, 2171-2194, doi:10.5194/acp-9-2171-2009, 2009.

Dameris, M., Grewe, V., Köhler, I., Sausen, P., Bruehl, C., Grooß, J., and Steil, B.: Impact of aircraft $\mathrm{NO}_{\mathrm{x}}$ emissions on tropospheric and stratospheric ozone, Part II, 3-D model results, Atmos. Environ., 32, 3185-3199, 1998.

Dentener, F., Kinne, S., Bond, T., Boucher, O., Cofala, J., Generoso, S., Ginoux, P., Gong, S., Hoelzemann, J. J., Ito, A., Marelli, L., Penner, J. E., Putaud, J.-P., Textor, C., Schulz, M., van der Werf, G. R., and Wilson, J.: Emissions of primary aerosol and precursor gases in the years 2000 and 1750 prescribed data-sets for AeroCom, Atmos. Chem. Phys., 6, 4321-4344, doi:10.5194/acp6-4321-2006, 2006.

Ellingsen, K., Gauss, M., Van Dingenen, R., Dentener, F. J., Emberson, L., Fiore, A. M., Schultz, M. G., Stevenson, D. S., Ashmore, M. R., Atherton, C. S., Bergmann, D. J., Bey, I., Butler, T., Drevet, J., Eskes, H., Hauglustaine, D. A., Isaksen, I. S. A., Horowitz, L. W., Krol, M., Lamarque, J. F., Lawrence, M. G., van Noije, T., Pyle, J., Rast, S., Rodriguez, J., Savage, N., Strahan, S., Sudo, K., Szopa, S., and Wild, O.: Global ozone and air quality: a multi-model assessment of risks to human health and crops, Atmos. Chem. Phys. Discuss., 8, 2163-2223, doi:10.5194/acpd- 
8-2163-2008, 2008.

Emanuel, K. A.: A scheme for representing cumulus convection in large-scale models, J. Atmos. Sci., 48, 2313-2335, 1991.

Emanuel, K. A.: A cumulus representation based on the episodic mixing model: the importance of mixing and microphysics in predicting humidity, AMS Meteorol. Monogr., 24(46), 185-192, 1993.

Endresen, Ø., Sørgård, E., Sundet, J. K., Dalsøren, S. B., Isaksen, I. S. A., Berglen, T. F., and Gravir, G.: Emission from international sea transportation and environmental impact, J. Geophys. Res., 108(D17), 4560, doi:10.1029/2002JD002898, 2003.

Endresen, O., Sorgard, E., Behrens, H., Brett, P., and Isaksen, I. S. A.: A historical reconstruction of ships' fuel consumption and emissions, J. Geophys. Res., 112, D12301, doi:10.1029/2006JD007630, 2007.

Eyers, C., Norman, P., Middel, J., Plohr, M., Michot, S., Atkinson, K., and Christou, R.: AERO2K Global Aviation Emissions Inventories for 2002 and 2025, Tech. Rep. 04/01113, QinetiQ, http://elib.dlr.de/1328, 2004.

Eyring, V., Köhler, H. W., and Lauer, A.: Emissions from international shipping: 1 . The last 50 years, J. Geophys. Res., 110, D17305, doi:10.1029/2004JD005619, 2005a.

Eyring, V., Köhler, H. W., Lauer, A., and Lemper, B.: Emissions from international shipping: 2. Impact of future technologies on scenarios until 2050, J. Geophys. Res., 110, D17306, doi:10.1029/2004JD005620, 2005b.

Eyring, V., Stevenson, D. S., Lauer, A., Dentener, F. J., Butler, T., Collins, W. J., Ellingsen, K., Gauss, M., Hauglustaine, D. A., Isaksen, I. S. A., Lawrence, M. G., Richter, A., Rodriguez, J. M., Sanderson, M., Strahan, S. E., Sudo, K., Szopa, S., van Noije, T. P. C., and Wild, O.: Multi-model simulations of the impact of international shipping on Atmospheric Chemistry and Climate in 2000 and 2030, Atmos. Chem. Phys., 7, 757-780, doi:10.5194/acp-7-757-2007, 2007.

Fiore, A. M., Dentener, J. F., Wild, O., Cuvelier, C., Schultz, M. G., Hess, P., Textor, C., Schulz, M., Doherty, R., Horowitz, L. W., MacKenzie, I. A., Sanderson, M. G., Shindell, D. T., Stevenson D. S., Szopa, S., Van Dingenen, R., Zeng, G., Atherton, C., Bergmann, D., Bey, I., Carmichael, G., Duncan, B. N., Faluvegi, G., Folberth, G., Gauss, M., Gong, S., Hauglustaine, D., Holloway, T., Isaksen, I. S. A., Jacob, D. J., Jonson, J. E., Kaminski, J. W., Keating, T. J., Lupu, A., Marmer, E., Montanaro, V., Park, R., Pitari, G., Pringle, K. J., Pyle, J. A., Schroeder, S., Vivanco, M. G., Wind, P., Wojcik, G., Wu, S., and Zuber, A.: Multimodel estimates of intercontinental source-receptor relationships for ozone pollution, J. Geophys. Res., 114, D04301, doi:10.1029/2008JD010816, 2009.

Folberth, G. A., Hauglustaine, D. A., Lathiére, J., and Brocheton, F.: Interactive chemistry in the Laboratoire de Météorologie Dynamique general circulation model: model description and impact analysis of biogenic hydrocarbons on tropospheric chemistry, Atmos. Chem. Phys., 6, 2273-2319, doi:10.5194/acp-62273-2006, 2006.

Fuglestvedt, J., Berntsen, T., Myhre, G., Rypdal, K., and Skeie, R. B.: Climate forcing from the transport sectors, Proc. Natl. Acad. Sci. USA, 105(2), 454-458, 2008.

Gauss, M., Isaksen, I. S. A., Lee, D. S., and Svde, O. A.: Impact of aircraft $\mathrm{NO}_{\mathrm{x}}$ emissions on the atmosphere - tradeoffs to reduce the impact, Atmos. Chem. Phys., 6, 1529-1548, doi:10.5194/acp-6-1529-2006, 2006

Granier, C. and Brasseur, P.: The impact of road traffic on global tropospheric ozone, Geophys. Res. Lett., 30(2), 1086, doi:10.1029/2002GL015972, 2003.

Granier, C., Niemeier, U., Jungclaus, J. H., Emmons, L., Hess, P., Lamarque, J. F., Walters, S., and Brasseur, P.: Ozone Pollution from Future Ship Traffic in the Arctic Northern Passages, Geophy. Res. Lett., L13807, doi:10.1029/2006GL026180, 2006.

Grewe, V.: Impact of climate variability on tropospheric ozone, Sci. Total Environ., 374, 167-181, 2007.

Grewe, V., Dameris, M., Fichter, C., and Sausen, R.: Impact of aircraft $\mathrm{NO}_{\mathrm{x}}$ emissions. Part 1: Interactively coupled climatechemistry simulations and sensitivities to climate-chemistry feedback, lightning and model resolution, Meteorol. Z., 11(3), 177-186, 2002.

Grewe, V., Tsati, E., and Hoor, P.: On the attribution of contributions of atmospheric trace gases to emissions in atmospheric model applications, Geosci. Model Dev., 3, 487-499, doi:10.5194/gmd-3-487-2010, 2010.

Hauglustaine, D. A., Granier, C., Brasseur, G. P., and Mégie, G.: Impact of present aircraft emissions of nitrogen oxides on tropospheric ozone and climate forcing, Geophys. Res. Lett., 21, 2031-2034, 1994.

Hauglustaine, D. A., Hourdin, F., Jourdain, L., Filiberti, M. A., Walters, S., Lamarque, J. F., and Holland, E. A.: Interactive chemistry in the Laboratoire de Météorologie Dynamique general circulation model: Description and background tropospheric chemistry evaluation, J. Geophys. Res., 109, D04314, doi:10.1029/2003JD003957, 2004.

Hauglustaine, D. A., Lathière, J., Szopa, S., and Folberth, G. A.: Future tropospheric ozone simulated with a climatechemistry biosphere model, Geophys. Res. Lett., 32, L24807, doi:10.1029/2005GL024031, 2005.

Heald, C. L., Wilkinson, M. J., Monson, R. K., Alo, C. A., Wang, G., and Guenther, A.: Response of isoprene emission to ambient $\mathrm{CO}_{2}$ changes and implications for global budgets, Glob. Change Biol., 15, 1127-1140, doi:10.1111/j.1365-2486.2008.01802.x , 2009.

Hedegaard, G. B., Brandt, J., Christensen, J. H., Frohn, L. M., Geels, C., Hansen, K. M., and Stendel, M.: Impacts of climate change on air pollution levels in the Northern Hemisphere with special focus on Europe and the Arctic, Atmos. Chem. Phys., 8, 3337-3367, doi:10.5194/acp-8-3337-2008, 2008.

Hewitt, C. D. and Griggs, D. J.: Ensembles-based Predictions of Climate Changes and their Impacts, Eos, 85, p. 566, 2004.

Hoor, P., Borken-Kleefeld, J., Caro, D., Dessens, O., Endresen, O., Gauss, M., Grewe, V., Hauglustaine, D., Isaksen, I. S. A., Jöckel, P., Lelieveld, J., Myhre, G., Meijer, E., Olivie, D., Prather, M., Schnadt Poberaj, C., Shine, K. P., Staehelin, J., Tang, Q., van Aardenne, J., van Velthoven, P., and Sausen, R.: The impact of traffic emissions on atmospheric ozone and $\mathrm{OH}$ : results from QUANTIFY, Atmos. Chem. Phys., 9, 3113-3136, doi:10.5194/acp-9-3113-2009, 2009.

Hourdin, F. and Armengaud, A.: The use of finite-volume methods for atmospheric advection of trace species: 1 . Test of various formulations in a general circulation model, Mon. Weather Rev., 127, 822-837, 1999.

Hourdin, F., Musat, I., Bony, S., Braconnot, P., Codron, F., Dufresne, J.-L., Fairhead, L., Filiberti, M.-A., Friedlingstein, P., 
Grandpeix, J.-Y., Krinner, G., Levan, P., Li, Z.-X., and Lott, F.: The LMDZ4 general circulation model: climate performance and sensitivity to parametrized physics with emphasis on tropical convection, Clim. Dynam., 27, 787-813, 2006.

Huszar, P., Cariolle, D., Paoli, R., Halenka, T., Belda, M., Schlager, H., Miksovsky, J., and Pisoft, P.: Modeling the regional impact of ship emissions on $\mathrm{NO}_{\mathrm{x}}$ and ozone levels over the Eastern Atlantic and Western Europe using ship plume parameterization, Atmos. Chem. Phys., 10, 6645-6660, doi:10.5194/acp-10-66452010, 2010.

IPCC, Climate Change 2001: The Scientific Basis. Contribution of Working Group I to the Third Assessment Report of the Intergovernmental Panel on Climate Change, edited by: Houghton, J. T., Ding, Y., Griggs, D. J., Noguer, M., van der Linden, P. J., Dai, X., Maskell, K., and Johnson, C. A., Cambridge University Press, Cambridge, United Kingdom and New York, NY, USA, 881 pp., 2001.

Isaksen, I. S. A., Zerefos, C., Kourtidis, K., Meleti, C., Dalsoren, S., Sundet, J., Grini, A., Zanis, P., and Balis, D.: Tropospheric ozone changes at unpolluted and semipolluted regions induced by stratospheric ozone changes, J. Geophys. Res., 110, 02302, doi:10.1029/2004JD004618, 2005.

Jöckel, P., Tost, H., Pozzer, A., Brühl, C., Buchholz, J., Ganzeveld, L., Hoor, P., Kerkweg, A., Lawrence, M. G., Sander, R., Steil, B., Stiller, G., Tanarhte, M., Taraborrelli, D., van Aardenne, J., and Lelieveld, J.: The atmospheric chemistry general circulation model ECHAM5/MESSy1: consistent simulation of ozone from the surface to the mesosphere, Atmos. Chem. Phys., 6, 50675104, doi:10.5194/acp-6-5067-2006, 2006.

Jonson, J. E., Stohl, A., Fiore, A. M., Hess, P., Szopa, S., Wild, O., Zeng, G., Dentener, F. J., Lupu, A., Schultz, M. G., Duncan, B. N., Sudo, K., Wind, P., Schulz, M., Marmer, E., Cuvelier, C., Keating, T., Zuber, A., Valdebenito, A., Dorokhov, V., De Backer, H., Davies, J., Chen, G. H., Johnson, B., Tarasick, D. W., Stübi, R., Newchurch, M.J., von der Gathen, P., Steinbrecht, W., and Claude, H.: A multi-model analysis of vertical ozone profiles, Atmos. Chem. Phys., 10, 5759-5783, doi:10.5194/acp10-5759-2010, 2010.

Jourdain, L. and Hauglustaine, D. A.: The global distribution of lightning $\mathrm{NO}_{\mathrm{x}}$ simulated on-line in a general circulation model, Phys. Chem. Earth, 26, 585-591, 2001.

Kahn Ribeiro, S., Kobayashi, S., Beuthe, M., Gasca, J., Greene, D., Lee, D., Muromachi, Y., Newton, P., Plotkin, S., Sperling, D., Wit, R., and Zhou, P.: Transport and its infrastructure, in: Climate Change 2007: Mitigation. Contribution of Working Group III to the Fourth Assessment Report of the Intergovernmental Panel on Climate Change, IPCC, edited by: Metz, B., Davidson, O., Bosch, P., Dave, R., and Meyer, L., Cambridge University Press, Cambridge, United Kingdom and New York, NY, USA, 2007.

Kentarchos, A. S. and Roelofs, G. J.: Impact of aircraft $\mathrm{NO}_{\mathrm{x}}$ emissions on tropospheric ozone calculated with a chemistrygeneral circulation model, Sensitivity to higher hydrocarbon chemistry, J. Geophys. Res., 107(4175), ACH 8, 1-12, doi:10.1029/2001JD000828, 2002.

Krinner, G., Viovy, N., De Noblet-Ducoudré, N., Ogee, J., Polcher, J., Friedlingstein, P., Ciais, P., Sitch, A., and Prentice, I.: A dynamical global vegetation model for studies of the coupled atmosphere-biosphere system, Global Biogeochem., Cy. 19,
GB1015, doi:10.1029/2003GB002199, 2005.

Lathière, J., Hauglustaine D., De Noblet-Ducoudré N., Krinner G., and Folberth, G.: Past and future changes in biogenic volatile organic compound emissions simulated with a global dynamic vegetation model, Geophys. Res. Lett., 32, L20818, doi:10.1029/2005GL024164, 2005.

Lathière, J., Hauglustaine, D. A., Friend, A. D., De NobletDucoudré, N., Viovy, N., and Folberth, G. A.: Impact of climate variability and land use changes on global biogenic volatile organic compound emissions, Atmos. Chem. Phys., 6, 2129-2146, doi:10.5194/acp-6-2129-2006, 2006.

Lawrence, M. G. and Crutzen, P. J.: Influence of $\mathrm{NO}_{\mathrm{x}}$ emissions from ships on tropospheric photochemistry and climate, Nature, 402, 167-170, 1999.

Le Treut, H., Li, Z. X., and Forichon, M.: Sensitivity of the LMD general circulation model to greenhouse forcing associated with two different cloud water parameterizations, J. Clim., 7, 18271841, 1994.

Le Treut, H., Forichon, M., Boucher, O., and Li, Z.-X.: Sulfate aerosol indirect effect and $\mathrm{CO}_{2}$ greenhouse forcing: Equilibrium response of the LMD GCM and associated cloud feebacks, J. Clim., 11, 1673-1684, 1998.

Lee, D. S., Köhler, I., Grobler, E., Rohrer, F., Sausen, R., GallardoKlenner, L., Olivier, J. G. J., Dentener, F. J., and Bouwman, A. F.: Estimations of global $\mathrm{NO}_{\mathrm{x}}$ emissions and their uncertainties, Atmos. Environ., 31, 1735-1749, 1997.

Li, D. and Shine, K. P.: A 4-D ozone climatology for UGAMP models, UGAMP internal report, UK Univ. Global Atmos. Model. Programme, Swindon, 1995.

Liao, H., Chen, W.-T., and Seinfeld, J. H.: Role of climate change in global predictions of future tropospheric ozone and aerosols, J. Geophys. Res., 111, D12304, doi:10.1029/2005JD006852, 2006.

Matthes, S., Grewe, V., Sausen, R., and Roelofs, G.-J.: Global impact of road traffic emissions on tropospheric ozone, Atmos. Chem. Phys., 7, 1707-1718, doi:10.5194/acp-7-1707-2007, 2007.

Meehl, G. A., Stocker, T. F., Collins, W. D., Friedlingstein, P., Gaye, A. T., Gregory, J. M., Kitoh, A., Knutti, R., Murphy, J. M., Noda A., Raper, S. C. B., Watterson, I. G., Weaver, A. J., and Zhao, Z.-C.: Global Climate Projections. in: Climate Change 2007: The Physical Science Basis. Contribution of Working Group I to the Fourth Assessment Report of the Intergovernmental Panel on Climate Change, edited by: Solomon, S., Qin, D., Manning, M., Chen, Z., Marquis, M., Averyt, K. B., Tignor, M., and Miller, H. L., Cambridge University Press, Cambridge,United Kingdom and New York, NY, USA, 2007.

Müller, J.-F. and Brasseur, G.: IMAGES: A three-dimensional chemical transport model of the global troposphere, J. Geophys. Res., 100, 16445-16490, 1995.

Murazaki, K. and Hess, P.: How does climate change contribute to surface ozone change over the United States?, J. Geophys. Res., 111, D05301, doi:10.1029/2005JD005873, 2006.

Myhre, G., Shine, K. P., Rädel, G., Gauss, M., Isaksen, I. S. A., Qi Tang, Prather, M. J., Williams, J., van Velthoven, P., Dessens, O., Koffi, B., Szopa, S., Hoor, P., Grewe, V., and Borken-Kleefeld, J.: Radiative forcing due to changes in ozone and methane caused by the transport sector, Atmos. Environ., 45, 387-394, doi:10.1016/j.atmosenv.2010.10.001, 2011.

Nakicenovic, N. and Swart, R. (Eds.): Special Report on Emissions 
Scenarios, 570 pp., Cambridge Univ. Press, New York, 2000.

Niemeier, U., Granier, C., Kornblueh, L., Walters, S., and Brasseur, G.: Global impact of road traffic on atmospheric chemical composition and on ozone climate forcing, J. Geophys. Res., 111, D09301, doi:10.1029/2006JD006407, 2006.

Olivier, J., van Aardenne, J., Dentener, F., Ganzeveld, L., and Peters, J.: Recent trends in global greenhouse gas emissions: regional trends and spatial distribution of key sources, in: Non$\mathrm{CO}_{2}$ Greenhouse Gases (NCGG-4), Millpress, Rotterdam, 325330, 2005.

Poisson, N., Kanakidou, M., and Crutzen, P. J.: Impact of nonmethane hydrocarbons on tropospheric chemistry and the oxidizing power of the global troposphere: 3-dimensional modeling results, J. Atmos. Chem., 36, 157-230, 2000.

Prather, M., Ehhalt, D., Dentener, F., Derwent, R., Dlugokencky, E., Holland, E., Isaksen, I., Katima, J., Kirchhoff, V., Matson, P., Midgley, P., and Wang, M.: Climate Change 2001, The scientific basis, in: Contribution of working group I to the Third assessment report of the Intergovernmental Panel on Climate, edited by: Houghton, J. T., Ding, Y., Griggs, D. J., Noguer, M., Linden, P. J., Dai, X., Maskell, K., and Johnson, C. A.,Cambridge University Press: Cambridge, United Kingdom and NewYork, USA, p. 881, 2001.

Reidmiller, D. R., Fiore, A. M., Jaffe, D. A., Bergmann, D., Cuvelier, C., Dentener, F. J., Duncan, B. N., Folberth, G., Gauss, M., Gong, S., Hess, P., Jonson, J. E., Keating, T., Lupu, A., Marmer, E., Park, R., Schultz, M. G., Shindell, D. T., Szopa, S., Vivanco, M. G., Wild, O., and Zuber, A.: The influence of foreign vs. North American emissions on surface ozone in the US, Atmos. Chem. Phys., 9, 5027-5042, doi:10.5194/acp-9-5027-2009, 2009.

Sadourny, R. and Laval, K.: January and July performance of the LMD general circulation model, in: New Perspectives in Climate Modelling, edited by: Berger, A. and Nicolis, C., Elsevier Sci., New York, 173-198, 1984.

Sausen, R., Isaksen, I., Grewe, V., Schumann, U., Hauglustaine, D., Lee, D., Myhre, G., Köhler, M., Pitari, G., Strordal, F., and Zerefos, C.: Aviation radiative forcing in 2000: An update on IPCC (1999), Meteorol. Z., 555-561, 2005.

Schnadt Poberaj, C., Staehelin, J., Bintanja, R., van Velthoven, P., Dessens, O., Gauss, M., Isaksen, I. S. A., Grewe, V., Jöckel, P., Hoor, P., Koffi, B., Hauglustaine, D., and Olivié, D.: QUANTIFY model evaluation of global chemistry models: carbon monoxide, Proceedings of an International Conference on Transport, Atmosphere and Climate, DLR Forschungsbericht 2010-10, ISSN 1434-8454, 163-168, 2010.

Schumann, U.: The impact of nitrogen oxides emissions from aircraft upon the atmosphere at flight altitudes - Results from the AERONOX project, Atmos. Environ., 31, 1723-1733, 1997.

Schumann, U., Schlager, H., Arnold, F., Ovarlez, J., Kelder, H., Hov, Ø., Hayman, G., Isaksen, I. S. A., Staehelin, J., and Whitefield, P.: Pollution from aircraft emissions in the North Atlantic Flight Corridor: Overview on the POLINAT projects, J. Geophys. Res., 105, 3605-3631, 2000

Søvde, O. A., Gauss, M., Isaksen, I. S. A., Pitari, G., and Marizy, C.: Aircraft pollution - a futuristic view, Atmos. Chem. Phys., 7, 3621-3632, doi:10.5194/acp-7-3621-2007, 2007.

Stevenson, D., Collins, W., Johnson, C., and Derwent, R.: The impact of aircraft nitrogen oxide emissions on tropospheric ozone studied with a 3-D Lagrangian model including fully diurnal chemistry, Atmos. Environ., 31, 1837-1850, 1997.

Stevenson, D. S., Dentener, F. J., Schultz, M. G., Ellingsen, K., van Noije, T. P. C., Wild, O., Zeng, G., Amann, M., Atherton, C. S., Bell, N., Bergmann, D. J., Bey, I., Butler, T., Cofala, J., Collins, W. J., Derwent, R. G., Doherty, R. M., Drevet, J., Eskes, H. J., Fiore, A. M., Gauss, M., Hauglustaine, D. A., Horowitz, L. W., Isaksen, I. S. A., Krol, M. C., Lamarque, J.-F., Lawrence, M. G., Montanaro, V., Müller, J.-F., Pitari, G., Prather, M. J., Pyle, A. J., Rast, S., Rodriguez, J. M., Sanderson, M. G., Savage, N. H., Shindell, D. T., Strahan, S. E., Sudo, K., and Szopa, S.: Multimodel ensemble simulations of present- day and near-future tropospheric ozone, J. Geophys. Res., 111, D08301, doi:10.1029/2005JD006338, 2006.

Stott, P. A., Jones, G. S., Lowe, J. A., Thorne, P., Durman, C.,Johns, T. C., and Thelen, J. C.: Transient Climate Simulations with the HadGEM1 Climate Model: Causes of Past Warming and Future Climate Change, J. Climate, 12, 2763-2782, 2006.

Uherek, E., Halenka, T., Borken-Kleefeld, J., Balkanski, Y., Berntsen, T., Borrego, C., Gauss, M., Hoor, P., Juda-Rezler, K., Lelieveld, J., Melas, D., Rypdal, K., and Schmid, S.: Transport Impacts on Atmosphere and Climate: Land Transport, Atmos. Environ., 44(37), 4772-4816, 2010.

Unger, N., Shindell, D. T., Koch, D. M., and Streets, D. G.: Air pollution radiative forcing from specific emissions sectors at 2030, J. Geophys. Res., 113, D02306, doi:10.1029/2007JD008683, 2008.

van Aardenne, J., Dentener, F., Olivier, J., Peters, J., and Ganzeveld, L.: The EDGAR3.2 Fast Track 2000 data set (32FT2000), available at: www.mnp.nl/edgar/model/ v32ft2000edgar/docv32ft2000, Joint Research Center, Institute for Environment and Sustainability (JRC-IES), Climate Change Unit, TP280, 21020 Ispra, Italy, 2005.

van Leer, B.: Towards the ultimate conservative difference scheme. Part IV: A new approach to numerical convection, J. Comput. Phys., 23, 276-299, 1977.

van der Werf, G. R., Randerson, J. T., Collatz, G. J., and Giglio, L.: Carbon emissions from fires in tropical and subtropical ecosystems, Glob. Change Biol., 9, 547-562, 2003.

van der Werf, G. R., Randerson, J. T., Giglio, L., Collatz, G. J., Kasibhatla, P. S., and Arellano Jr., A. F.: Interannual variability in global biomass burning emissions from 1997 to 2004, Atmos. Chem. Phys., 6, 3423-3441, doi:10.5194/acp-6-3423-2006, 2006.

Wang, Y. H., Jacob, D. J., and Logan, J. A.: Global simulation of tropospheric $\mathrm{O} 3-\mathrm{NO}_{\mathrm{x}}$-hydrocarbon chemistry, 1. model formulation, J. Geophys. Res., 103, 10713-10725, 1998.

Wauben, W., van Velthoven, P., and Kelder, H.: A 3-D chemistry transport model study of the changes in atmospheric ozone due to aircraft $\mathrm{NO}_{\mathrm{x}}$ emissions, Atmos. Environ., 31, 1819-1836, 1997.

Wu, S., Mickley, L. J., Jacob, D. J., Rind, D., and Streets, D. G.: Effects of 2000-2050 changes in climate and emissions on global tropospheric ozone and the policy-relevant background surface ozone in the United States, J. Geophys. Res., 113, D18312,doi:10.1029/2007JD009639, 2008.

Zhao, C., Wang, Y., Choi, Y., and Zeng, T.: Summertime impact of convective transport and lightning $\mathrm{NO}_{\mathrm{x}}$ production over North America: modeling dependence on meteorological simulations, Atmos. Chem. Phys., 9, 4315-4327, doi:10.5194/acp-9-43152009, 2009. 